\title{
Cactaceae no estado do Paraná, Brasil
}

\author{
Cactaceae in the state of Paraná, Brasil
}

André Soller ${ }^{1,3}$, Patrícia Soffiatti ${ }^{1}$, Alice Calvente ${ }^{2}$ \& Renato Goldenberg ${ }^{1}$

\begin{abstract}
Resumo
Este trabalho apresenta o estudo taxonômico de Cactaceae no estado do Paraná. A metodologia inclui a análise de coleções de herbário e realização de coletas em todos os biomas do estado. Doze gêneros e 26 espécies nativas foram inventariados para o estado. Os gêneros mais ricos são Rhipsalis, representado por 11 espécies, Lepismium (4) e Schlumbergera (2). Os outros nove gêneros estão representados por apenas uma espécie cada: Brasiliopuntia brasiliensis, Cereus hildmannianus, Epiphyllum phyllanthus, Hatiora salicornioides, Hylocereus setaceus, Opuntia monacantha, Parodia carambeiensis, Pereskia aculeata e Praecereus euchlorus. O Paraná representa o limite norte de ocorrência no Brasil de S. rosea e S. gaertneri e limite sul de ocorrência de B. brasiliensis, H. salicornioides e R. pilocarpa. Parodia carambeiensis é a única Cactaceae endêmica do estado. São apresentadas descrições, chaves para identificação de gêneros e espécies, ilustrações e comentários taxonômicos.
\end{abstract}

Palavras-chave: flora do Paraná, florística, Rhipsalis, taxonomia.

\begin{abstract}
A taxonomic survey of the Cactaceae from Paraná state, Brazil, is presented here. Methodology includes an analysis of herbarium specimens and fieldwork in all biomes in the state. Twelve genera and 26 native species were catalogued for Paraná. The richest genera are Rhipsalis, with 11 species, Lepismium (4), and Schlumbergera (2). The other genera are monospecific: Brasiliopuntia brasiliensis, Cereus hildmannianus, Epiphyllum phyllanthus, Hatiora salicornioides, Hylocereus setaceus, Opuntia monacantha, Parodia carambeiensis, Pereskia aculeata and Praecereus euchlorus. Paraná state is the northern limit of S. rosea and S. gaertneri, and the southern limit of B. brasiliensis, H. salicornioides and R. pilocarpa. Parodia carambeiensis is the only endemic species of Cactaceae in the state. We present descriptions, identification keys, illustrations, and comments on the taxonomy of these species.
\end{abstract}

Key words: flora of Paraná, flora, Rhipsalideae, taxonomy.

\section{Introdução}

Cactaceae Juss. compreende cerca de 124 gêneros e 1438 espécies com distribuição restrita às Américas, à exceção de Rhipsalis baccifera (J.M. Muell) Stearn., que se estende até à África e à Ásia (Hunt et al. 2006). Os principais centros de endemismo da família estão localizados no México e Sudoeste dos EUA, Cordilheira dos Andes e Leste do Brasil (Taylor \& Zappi 2004; Hunt et al. 2006).

O monofiletismo da família é sustentado por sinapormorfias morfológicas como folhas reduzidas, modificadas em espinhos, os caules suculentos, as aréolas, a presença do pericarpelo, o embrião curvo e o perisperma na semente (Barthlott \& Hunt 1993) e também por dados moleculares obtidos a partir de DNA de cloroplasto (Nyffeler 2002; Wallace \& Gibson 2002). Cactaceae está subdividida em quatro subfamílias:Cactoideae, Maiuhenioideae, Opuntioideae e Pereskioideae, sendo que apenas as duas últimas são reconhecidamente monofiléticas por caracteres morfológicos e moleculares (Nyffeler 2002; Wallace \& Gibson 2002; Edwards et al. 2005; Hunt 2006).

No Brasil ocorrem 37 gêneros e cerca de 230 espécies de Cactaceae distribuídas por todo

\footnotetext{
${ }^{1}$ Universidade Federal do Paraná, Depto. Botânica, C.P. 19031, 81531-980, Curitiba, PR, Brasil.

${ }^{2}$ Universidade Federal do Rio Grande do Norte, Centro de Biociências, Depto. Botânica, Ecologia Zoologia (DBEZ), 59072-970, Natal, RN, Brasil.

${ }^{3}$ Autor para correspondência: biosoller@yahoo.com.br
} 
o território do país (Zappi et al. 2010). Todas as subfamílias, exceto Maiuhenioideae, estão representadas no Brasil e a região leste apresenta grande endemismo da família (Taylor \& Zappi 2004). Embora muito bem representada na nossa flora, há uma notória escassez de trabalhos sobre a família no sul do Brasil, especialmente no Paraná. Os únicos trabalhos que tiveram por objetivo o levantamento de espécies de Cactaceae neste estado são o de Angely (1965), que listou as espécies que ocorrem no estado, citando seis gêneros e 25 espécies; Oliveira Jr. (2007), que realizou um levantamento das espécies que ocorrem no Parque Estadual de Vila Velha, citando cinco gêneros e 11 espécies; a listagem da Flora do Brasil (Zappi et al. 2010), que considerou 10 gêneros e 30 espécies de Cactaceae para o estado e o "Catálogo de las plantas vasculares del Cono Sur" (Zuloaga et al. 2008), onde os autores listaram as espécies do Cone Sul incluindo o Paraná.

Este trabalho tem o objetivo de realizar o estudo taxonômico da família Cactaceae no Paraná. São fornecidas chaves de identificação, ilustrações e comentários taxonômicos. Descrições completas e listas de exsicatas estão disponibilizadas no sítio eletrônico da revista.

\section{Material e Métodos}

Foram realizadas coletas em todos os biomas do estado e as exsicatas foram depositadas no herbário UPCB. Foram analisadas as coleções dos herbários FUEL, FUEM, HCF, MBM, RB, SP, SPF, UEC e UPCB (siglas segundo Thiers 2012), e as obras sobre Cactaceae (Schumann 1890; Loefgren 1915, 1917; Britton \& Rose 1923; Gibson \& Nobel 1986; Barthlott \& Hunt 1993; Barthlott \& Taylor 1995; Wallace 1995; Wallace \& Cota 1996; Taylor 1997; Anderson 2001; Nyffeler 2002; Taylor \& Zappi 2004; Hunt et al. 2006), bem como os estudos taxonômicos das floras de Santa Catarina (Scheinvar 1985) e de São Paulo (Zappi et al. 2007).

Esse estudo segue as definições da classificação da vegetação apresentadas em Veloso et al. (1991).

No presente estudo foram consideradas apenas as espécies nativas. Táxons infraespecíficos (subespécies) não foram considerados. A distribuição geográfica das espécies foi descrita com base nos espécimes analisados, nos dados obtidos na bibliografia e nas áreas de coletas. A chave para identificação de gêneros foi confeccionada com dados das espécies encontradas no Paraná, enquanto as descrições de gêneros foram obtidas na literatura (Anderson 2001; Taylor \& Zappi 2004) e no material examinado.

Os caracteres da morfologia geral foram descritos baseados nos termos e definições adotadas em Lawrence (1955) e Gonçalves \& Lorenzi (2007). Os caracteres específicos da família foram descritos baseados em observação pessoal e em termos e definições adotadas por Taylor \& Zappi (2004). O termo "caule alado" é utilizado unicamente para as epífitas, enquanto que o termo "caule costelado" é utilizado para as terrícolas e ambos se referem às projeções do caule. Já o termo "caule aplanado" é utilizado para os gêneros terrícolas Brasiliopuntia e Opuntia, pois o caule todo é achatado. O termo "aréola" se refere às estruturas que consistem de um conjunto de meristemas axilares e ramos encurtados, que ocorrem ao longo do caule das espécies de Cactaceae, de onde se originam os espinhos, ramos e botões florais. O termo "podário" se refere aos espessamentos encontrados no caule, na porção que subtende as aréolas. O termo "pericarpelo" trata da estrutura composta pela parte inferior da flor, onde o ovário está imerso (Taylor \& Zappi 2004).

\section{Resultados e Discussão}

Doze gêneros e 26 espécies foram considerados nativos do Paraná. Destaca-se Parodia carambeiensisque é a única espécie de Cactaceae endêmica do estado. Não foram incluídas neste trabalho Epiphyllum oxypetalum Haw., Nopalea cochenillifera (L.) Salm-Dyck e Pereskia grandifolia Haw., as quais apesar de constarem nos herbários como provenientes do Paraná, não foram coletadas em locais de vegetação nativa e, deste modo, foram consideradas como espécies exóticas cultivadas.

A maior concentração dos cactos epífitos paranaenses está localizada na região leste do estado, nas Floresta Ombrófila Densa e Mista, e a maior concentração dos cactos terrícolas está nas regiões do centro e do oeste do estado, sendo encontrados nos remanescentes de Estepes e de Floresta Estacional Semidecidual.

Observações em campo mostram que os espécimes estão restritos às Unidades de Conservação presentes no território paranaense e em raros lugares onde há vegetação nativa. $\mathrm{O}$ caso mais preocupante é o de Rhipsalis trigona, coletada pela última vez em 1989, em Turvo (G. Hatschbach $53166 \mathrm{MBM}$ ) e que, mesmo após várias visitas ao local de ocorrência, não foi novamente encontrada. 


\section{Chave para identificação dos gêneros de Cactaceae do Paraná}

1. Folhas regulares, com mais de $2 \mathrm{~cm}$ compr. 9. Pereskia

1'. Folhas ausentes ou cilíndricas, neste caso com menos de $1 \mathrm{~cm}$ compr.

2. Caule costelado.

3. Plantas com menos de $20 \mathrm{~cm}$ compr., globosas

8. Parodia

3'. Plantas com mais de $1 \mathrm{~m}$ compr., colunares.

4. Caule 58-165 mm diâm.; costelas 14-57 mm larg.

4'. Caule 37-45 mm diâm.; costelas 7-9 mm larg. 10. Praecereus

2'. Caule cilíndrico, clavado, angulado, alado ou aplanado.

5. Plantas terrícolas, eretas, maiores que $1 \mathrm{~m}$ compr.

6. Plantas com mais de $4 \mathrm{~m}$ alt.; segmentos do caule dimórficos, os primários cilíndricos e os secundários aplanados 1. Brasiliopuntia

6'. Plantas com menos de $4 \mathrm{~m}$ alt.; segmentos do caule monomórficos aplanados

7. Opuntia

5'. Plantas epífitas, escandentes ou rupícolas, pendentes ou eretas, neste caso, menores que $0,7 \mathrm{~m}$ compr.

7. Flores com mais de $15 \mathrm{~cm}$ compr.; frutos com mais de $3 \mathrm{~cm}$ compr.

8. 2 alas na região mediana e cilíndrico na base; flores $17-19 \mathrm{~cm}$ compr.

8'. 3 alas; flores $23-31 \mathrm{~cm}$ compr.

7'. Flores com menos de $10 \mathrm{~cm}$ compr.; fruto com menos de $2 \mathrm{~cm}$ compr.

9. Caule clavado

5. Hylocereus

9'. Caule cilíndrico, angulado ou alado.

10. Caule alado com flores apicais

4. Hatiora

10'. Caule cilíndrico, angulado ou alado, neste caso, com flores laterais.

11. Ramificação apical, lateral ou subapical; segmentos monomórficos ou os secundários com crescimento determinado; escamas da aréola estéril filiformes ou ausentes

11. Rhipsalis

11'. Ramificação estritamente lateral ou subapical; segmentos caulinares todos com crescimento indeterminado; escamas da aréola estéril triangulares

6. Lepismium

\section{Brasiliopuntia A. Berger., Entwickly. Kakteen} 17, 18.94. 1926.

1.1 Brasiliopuntia brasiliensis (Willd.) A. Berger., Entwickl. Kakteen 17, 18, 94. 1926. Fig. 1a-b

Terrícolas ou rupícolas até $20 \mathrm{~m}$ compr., eretas. Caules castanhos ou esverdeados, ramificações apicais, subapicais ou laterais, 2-furcados, segmentos com formato dimórfico; segmentos primários cilíndricos, 9-18 × 0,32$2,8 \mathrm{~cm}$, crescimento determinado; segmentos secundários aplanados, estreito-elípticos, base aguda, ápice arredondado, margens lisas, 5-14 × $3,4-10,8 \mathrm{~mm}$, crescimento determinado. Aréolas estéreis 0,8-2 mm larg., aréolas estéreis com ou sem 1 espinho aciculado, 1,1-25 mm compr., gloquídios castanhos, 1,5-3 mm compr., folhas cilíndricas, decíduas 1,4-4,7 mm compr., aréolas férteis 2,2-5 $\mathrm{mm}$ larg., lanosas, podários não desenvolvidos. Flores 1 por aréola, 1,3-3,5 × 1,2-2,1 cm, apicais, subapicais ou laterais, rotáceas; pericarpelos esverdeados, $0,8-3,6 \times 0,7-1,1 \mathrm{~cm}$, emersos do caule, piriformes, cobertos de aréolas estéreis; segmentos externos do perianto amarelados, 4,5-7 $\times 3-6 \mathrm{~mm}$, eretos, triangulares a obovais; segmentos internos do perianto amarelados com centros mais escuros, 10-18 × 4-6 mm, eretos, oblanceolados a obovais. Frutos verde-amarelados a vináceos, $2-3,8$ $\times 1,4-2,9 \mathrm{~cm}$, elípticos a globosos. Sementes $1-2$, castanhas, 6,5-9,1 × 6-7,6 mm, globosas.

Material selecionado: Diamante do Norte, E.E. Caiuá, 30.XI.2000, C.M. Sakuragui 1.281 (HUEM). Ubiratã, 18.X.2008, fl., E.S. Sekine 84 (HCF).

Brasiliopuntia brasiliensis é caracterizada por possuir segmentos caulinares primários cilíndricos, dos quais surgem os segmentos caulinares aplanados, ou cladódios. Ocorre naturalmente na Estação Ecológica do Caiuá, em sub-bosque de Floresta Estacional Semidecidual no Paraná. O estado representa o limite sul de ocorrência da espécie no Brasil. Difere de Opuntia monacantha Haw. pois esta não apresenta os segmentos primários cilíndricos. 


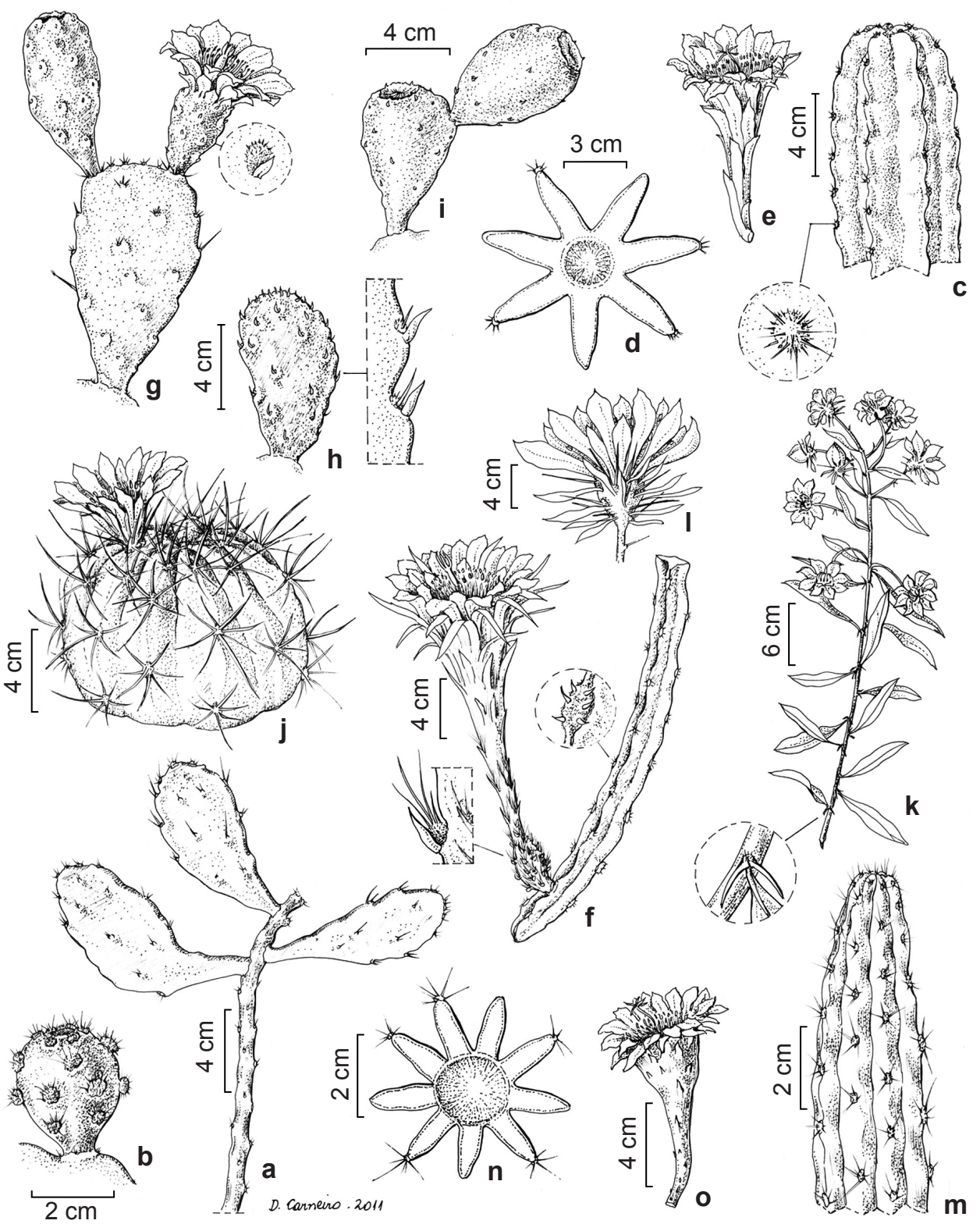

Figura 1 - a-b. Brasiliopuntia brasiliensis(Willd.) A. Berger - a. ramo; b. fruto (Labiak 4666). c-e. Cereus hildmannianus K. Schum. - c. ápice do caule com destaque da aréola estéril; d. corte transversal do caule; e. flor (Oliveira 325). f. Hylocereus setaceus (Salm-Dick) Bauer - ramo com flor e destaque das aréolas estéreis do pericarpelo e do caule (Abrão 49). g-i. Opuntia monacantha Haw - g. ramo com flor e fruto e destaque da aréola estéril; h. segmento secundário jovem com destaque das aréolas estéreis com folhas cilíndricas; i. frutos (Soller 160). j. Parodia carambeiensis (Buining \& Brederoo) Hofacker - ramo com flor (Oliveira 368). k-1. Pereskia aculeata Mill - k. ramo com flor e destaque da aréola estéril; 1. flor (Silva s/n UPCB 33167). m-o. Praecerus euchlorus (F.A.C.Weber) N.P.Taylor - m. ápice do caule; n. corte transversal do caule; o. flor (Hatschbach 19098).

Figure 1 - a-b. Brasiliopuntia brasiliensis (Willd.)A. Berger - a. branch; b. fruit (Labiak 4666). c-e. Cereus hildmannianus K. Schum - c. stem apex with sterile areole; d. transversal section of the stem; e. flower (Oliveira 325). f. Hylocereus setaceus (Salm-Dick) Bauer. - branch with flower and sterile areoles on the pericarpel and stem (Abrão 49). g-i. Opuntia monacantha Haw - g. branch with flower, fruit and sterile areole; h. young secondary cladode with sterile areoles bearing cillindric leaves; i. fruits (Soller 160). j. Parodia carambeiensis (Buining \& Brederoo) Hofacker - branch with flower (Oliveira 368). k-1. Pereskia aculeata Mill - k. branch with flower and sterile areole;1. flower (Silva s/n UPCB 33167). m-o. Praecerus euchlorus (F.A.C.Weber) N.P.Taylor - m. stem apex; $\mathrm{n}$. transversal section of the stem; o. flower (Hatschbach 19098). 
2. Cereus Mill., Gard. Dict. Abr. ed. 4.1754.

2.1 Cereus hildmannianus K. Schum in Mart., Fl. bras. 4(2): 202, 1890.

Fig. 1c-e

Rupícolas ou terrícolas até $15 \mathrm{~m}$ compr., eretas. Caules esverdeados, ramificações subapicais ou laterais, 2-furcados, segmentos com formato monomórfico, costelados, 4-7 costelas, 1,4-5,7 cm larg. $\times$ 0,6-1,5 cm esp., 5,8-16,5 cm diâm., crescimento determinado. Aréolas estéreis 3-7 $\mathrm{mm}$ larg., aréolas férteis 3-9 $\mathrm{mm}$ larg., aréolas estéreis e férteis lanosas com tricomas acinzentados e (1)-3-4-5-(6)-(7) espinhos castanhos, 0,4-22 $\mathrm{mm}$ compr., podários não desenvolvidos. Flores 1-(2) por aréola, $12-21 \times 5-8 \mathrm{~cm}$, laterais, infundibuliformes; pericarpelos esverdeados, $5,7-13 \times 0,7-4,6 \mathrm{~cm}$, emersos do caule, piriformes, cobertos de aréolas estéreis, estas, recobertas por escamas; segmentos externos do perianto esverdeados com extremidades vináceas a róseas, $1,7-4 \times 0,8-1,6 \mathrm{~cm}$, patentes a eretos, lanceolados; segmentos internos do perianto alvos a róseos, $6-10 \times 0,8-1,8 \mathrm{~cm}$, patentes, lanceolados; estames alvos, 7-14 cm; estilete 7-15 cm compr. Frutos esverdeados a amarelados, 2,9-6 × 1,7-3 cm, globosos a elípticos. Sementes 35-43, negras, 2,2-3,2 $\times 1,4-1,8 \mathrm{~mm}$, elípticas a reniformes.

Material selecionado: Candói, Três Pinheiros, 18.IV.2004, fr., R. Goldenberg 677 (MBM). Campo Mourão, P.E. Lago Azul, 21.XI.2007, fl., M.G. Caxambu 1951 (HCF). Ponta Grossa, 28.I.1996, fl., H.F.Oliveira 325 (UPCB). Sapopema, Salto das Orquídeas, 11.X.1997, fl., C. Medri 470 (FUEL). Tibagi, 12.XII.1989, fr., M.C. Dias (FUEL 7858).

Cereus hildmannianus é um cacto colunar de porte arborescente podendo apresentar a base do caule recoberta por periderme. É encontrado no centro e no oeste do Paraná na Floresta Estacional Semidecidual e ocorre geralmente em afloramentos rochosos. Difere de Praecereus euchlorus (F.A.C. Weber) N.P. Taylor, pois este alcança $4 \mathrm{~m}$ compr. e 37-45 mm diâm. enquanto $C$. hildmannianus alcança até $15 \mathrm{~m}$ compr. e 58-165 mm diâm.

3. Epiphyllum Haw., Syn. pl. succ. 197. 1812. 3.1 Epiphyllum phyllanthus (L.) Haw., Syn. Pl. Succ. 197. 1812.

Fig. 2a-b

Epífitas até 1,5 m compr., pendentes. Caules esverdeados, ramificações subapicais ou laterais, 2(-3)-furcados, segmentos com formato dimórfico; segmentos primários cilíndricos, 24$46 \mathrm{~mm} \times 4,4-5,1 \mathrm{~mm}$, crescimento indeterminado; segmentos secundários 2-alados na região mediana e do ápice e cilíndricos na base, alas contínuas, lineares a estreito-elípticos, base atenuada, ápice agudo a cuneado, margens crenadas, ápice das projeções das margens dos caules arredondados, $28-150 \mathrm{~cm} \times 32-87 \mathrm{~mm} \times 1-4 \mathrm{~mm}$, nervura central 4-5 mm larg., crescimento indeterminado. Aréolas estéreis $0,7-1,5 \mathrm{~mm}$ larg., aréolas férteis 1,7-5 mm larg., aréolas estéreis e férteis lanosas, podários não desenvolvidos. Flores 1 por aréola, $17-19 \mathrm{~cm} \times 25-36 \mathrm{~mm}$, laterais, infundibuliformes; pericarpelos esverdeados, $15-16 \mathrm{~cm} \times 2-4 \mathrm{~mm}$, emersos do caule, cobertos por escamas filiformes a lineares, 4-11mm compr.; segmentos externos do perianto alvos a esverdeados, $14-18 \times 1-3 \mathrm{~mm}$, eretos, lanceolados a estreito-elípticos; segmentos internos do perianto alvos, $14-18 \times 1-2 \mathrm{~mm}$, eretos, lanceolados a estreito-elípticas. Frutos vináceos, 49-52 × 38-43 mm, globosos a elípticos. Sementes 115-121, negras, 3,2-4,4 × 1,6-2,2 mm, reniformes.

Material selecionado: Campo Mourão, P.M. Ingá, 19.XI.2009, fl., E.G. Paulino 57 (HCF). Londrina, 22.II.2011, fr., A. Soller 117 (UPCB).

Epiphyllum phyllanthus é caracterizado pelo caule alado, de crescimento indeterminado, que alcança $1,5 \mathrm{~m}$ compr., flor ca. $19 \mathrm{~cm}$ compr. e fruto maior que $5 \mathrm{~cm}$ compr. Ocorre no norte do Paraná, na região da Floresta Estacional Semidecidual. Difere de Lepismium houlletianum, pois este possui o caule menor, ca. $40 \mathrm{~cm}$ compr., flores ca. $2 \mathrm{~cm}$ compr. e frutos ca. $1 \mathrm{~cm}$ compr.

4. Hatiora Britton \& Rose, in L.H. Bailey, Stand. Cycl. Hort 3: 1432. 1915.

4.1 Hatiora salicornioides (Haw.) Britton \& Rose in L.H. Bailey, Standard Cycl. Hortic. 1433. 1915.

Fig. 2c-d

Epífitas ou rupícolas até $1 \mathrm{~m}$ compr., pendentes. Caules esverdeados, ramificações apicais, 2-3-4-(5)-(7)-furcados, segmentos com formato monomórfico, clavados, $12-45 \mathrm{~mm} \times$ 1,5-5,5 $\mathrm{mm}$, crescimento determinado. Aréolas estéreis $0,3-0,7 \mathrm{~mm}$ larg., aréolas férteis 1,3-3,2 $\mathrm{mm}$ larg., aréolas estéreis e férteis lanosas e com escamas, podários não desenvolvidos. Flores 1 por aréola, 8,4-13 × 5-7,1 mm, apicais, campanuladas; pericarpelos esverdeados com a bases avermelhadas, 2,2-3,9 × 3-5 mm, emersosdo caule, piriformes, glabros; segmentos externos do perianto 4, amarelados, $0,7-3 \times 1-3 \mathrm{~mm}$, eretos, triangulares a obovados; segmentos internos do perianto 14-15, amarelados, 2,5-9 mm $\times 1,4-4,9$ $\mathrm{mm}$, eretos, estreito-elípticos a oblongos; estames 


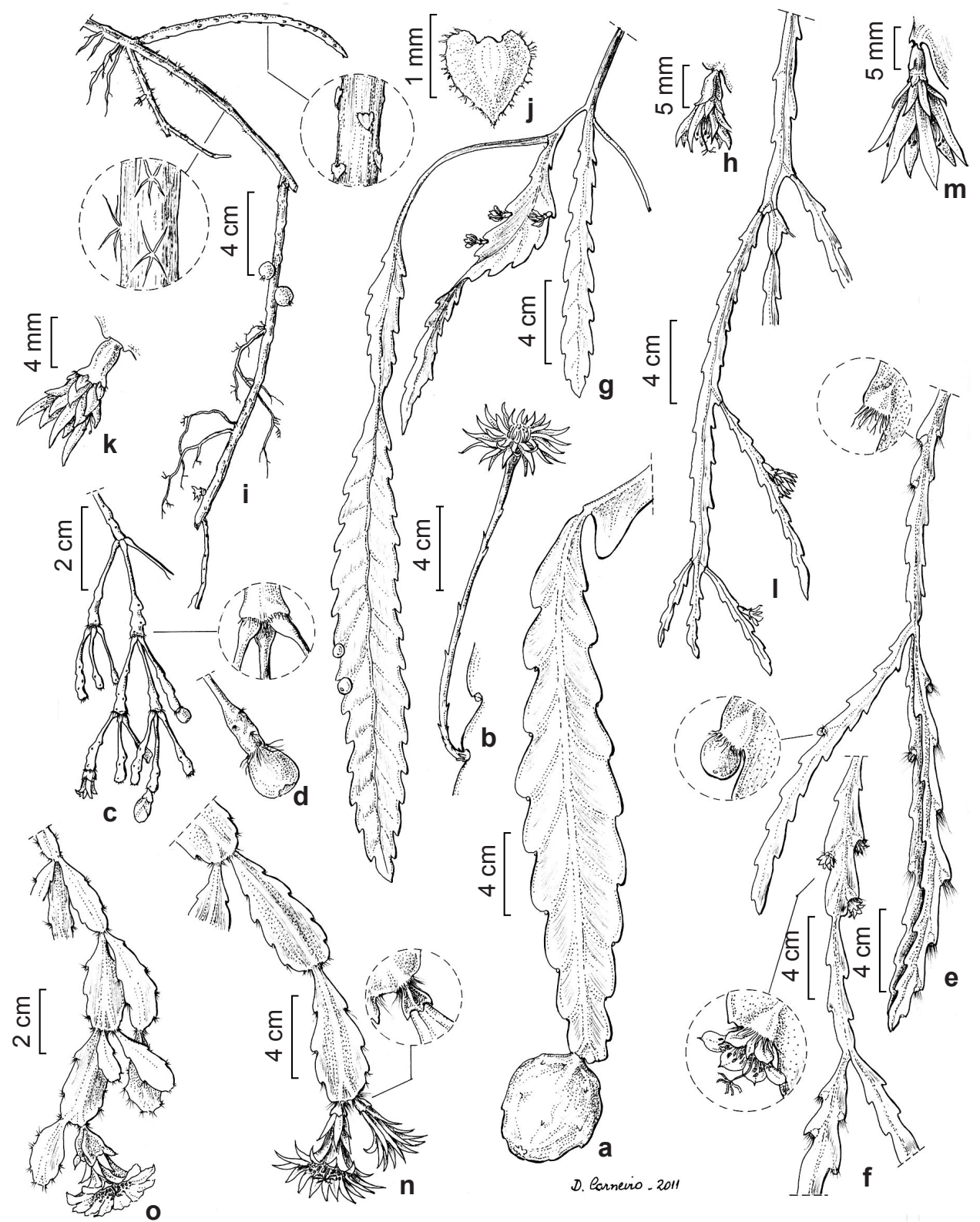

Figura 2 - a-b. Epiphylum phyllanthus (L.) Haw - a. ramo com fruto (Soller 117); b. flor (Paulino 57). c-d. Hatiora salicornioides (Haw.) Britton \& Rose - c. ramo com botão e fruto e destaque da ramificação; d. fruto (Borgo 932). e-f. Lepismium cruciforme (Vell.) Miq - e. ramo com destaque da aréola fértil e do fruto (Oliveira 331); f. ramo com destaque da flor (Cervi 6885). g-h. Lepismium houlletianum (Lem.) Barthlott-g. ramo com flor e fruto; h. flor (Petean 64). i-k. Lepismium lumbricoides (Lem.) Barthlott - i. ramo com fruto e destaque das aréolas estéreis; j. escama triangular (Kersten $s / n$ UPCB 43485); k. flor (Borgo 773). 1-m. Lepismium warmingianum (K. Schum.) Barthlott - 1. ramo com flor; m. flor (Soller 138). n. Schlumbergera gaertneri (Regel) Britton \& Rose - ramo com flor e destaque do pericarpelo (Cervi 3891). o. Schlumbergera rosea (Lagerh.) Calvente \& Zappi - ramo com flor (Cervi 7053).

Figure 2 - a-b. Epiphylum phyllanthus (L.) Haw -a. branch with fruit (Soller 117); b. flower (Paulino 57). c-d. Hatiora salicornioides (Haw.) Britton \& Rose - c. branch with flower bud, fruit, and branching pattern; d. fruit (Borgo 932). e-f. Lepismium cruciforme (Vell.) Miq. - e. branch with fruit and fertile areole (Oliveira 331); f. branch with flower (Cervi 6885). g-h. Lepismium houlletianum (Lem.) Barthlott - g. branch with flower and fruit; h. flower (Petean 64). i-k. Lepismium lumbricoides (Lem.) Barthlott - i. branch with fruit and sterile areoles; j. triangular scale (Kersten s/n UPCB 43485); k. flower (Borgo 773). 1-m. Lepismium warmingianum (K. Schum.) Barthlott - 1. branch with flower;m. flower (Soller 138). n. Schlumbergera gaertneri (Regel) Britton \& Rose - branch with flower and pericarpel (Cervi 3891). o. Schlumbergera rosea (Lagerh.) Calvente \& Zappi - branch with flower (Cervi 7053). 
50-76, alvos, 1,6-6,9 mm compr.; estiletes 4,8-6,2 mm compr., lobos 4-5, 0,9-1,3 mm compr. Frutos alvos, róseos ou vináceos, 5,9-7,9 × 5-6,1 mm, piriformes. Sementes 11-97, castanhas, 0,8-1,2 $\times$ 0,4-0,7 mm, piriformes.

Material selecionado: Araucária, Taquarova, 28.VIII.1993, fr., A.L. Schiitz (UPCB 27848). Curitiba, Capão Jd. Botânico, 21.I.1991, fr., D. Galli 18 (UPCB). Jaguariaíva, 20.XI.1995, fr., A.C. Cervi 6046 (UPCB). Pinhais, 20.X.1999, fl., M.P. Petean 87 (UPCB). Ponta Grossa, Buraco do Padre, 15.XII.1995, fr., H.F. Oliveira 339 (UPCB).

Hatiora salicornioides é caracterizada pelos segmentos do caule clavados e ocorre na Floresta Ombrófila Mista e Floresta Estacional Semidecidual do Paraná. O estado representa o limite sul de ocorrência da espécie no Brasil. Difere de Hatiora cylindrica Britton \& Rosee, Hatiora herminiae (Porto \& Castell.) Backeb. ex. Barthlott que possuem caule cilíndrico, e pela coloração da flor que em $H$. herminiae é rósea.

5. Hylocereus (A.Berger) Britton \& Rose, Contr. U.S. Natl. Herb. 12:428. 1909.

5.1 Hylocereus setaceus (Salm-Dyck ex DC.) Bauer, Cactaceae Syst. Init. 17:29. 2003. Fig. If

Escandentes ou epífitas até $4 \mathrm{~m}$ compr., eretas ou pendentes. Caules esverdeados, ramificações subapicais ou laterais, 2-furcados, segmentos com formato monomórfico, alados, 3 alas, 7,9-17 mm larg. × 3-8 mm esp., indeterminados. Aréolas estéreis 3-6 mm larg., lanosas com 1-2-(4)-(5) espinhos castanhos, 1-3,7 mm compr., aréolas férteis 5-8 mm larg., lanosas, podários não desenvolvidos. Flores 1 por aréola, 23-31 $\times$ 5-12 cm, laterais, infundibuliformes; pericarpelos esverdeados, 11-19 $\mathrm{cm} \times 18-26 \mathrm{~mm}$, emersos do caule, piriformes, cobertos por aréolas com espinhos e brácteas; segmentos externos do perianto alvos, 18-98 × 3-7,8 mm, patentes, lanceolados; segmentos internos do perianto alvos, 7-14 cm $\times$ 6,3-8 mm, patentes, lanceolados. Frutos não vistos. Material selecionado: Pinhão, Rio Divisa, 20.IX.1991, fl., H.R.S. Abrão 49 (MBM). Porto Rico, Rio Paraná, 30.X.2002, fl., V. Tomazini 491 (HUEM).

Hylocereus setaceus pode ser reconhecido por possuir caule com seção trígona. Ocorre naturalmente nos paredões do Rio Paraná, região de Floresta Estacional Semidecidual no Paraná. Difere de Hylocereus undatus, não considerado nativo por ser encontrado apenas em áreas antropizadas, pela borda da margem do caule lisa e pericarpelo com aréolas espinescentes enquanto a espécie exótica possui a margem do caule crenada e não possui aréolas espinescentes no pericarpelo.

6. Lepismium Pfeiff., in Otto \& Dietr., Allg. Gartenz. 3: 315. 1835.

Plantas arbustivas, epífitas ou rupícolas, 0,5-2 m compr., pendentes, ramificação subapical ou lateral. Caule segmentado, monomórfico ou dimórfico, cilíndricos, 30-100 × 0,4-0,8 cm ou 2-(3)-(4)-(5)-alados, 10-50 × 0,7-5 cm, com crescimento indeterminado. Folhas ausentes. Aréolas dispostas nas margens das alas ou ao redor do caule nas espécies cilíndricas, glabra, pubescente, tomentosa ou lanosa e com escama triangular perene; espinhos ausentes. Flores 1 a 2,2 cm compr., laterais, rotáceas ou campanuladas, alvas a esverdeadas ou róseas; pericarpelo glabro ou com aréolas; antese diurna. Frutos globosos,ovais ou angulados, 4,8-15 mm compr., alvos, róseos ou vináceos. Sementes castanhas, lisas, elípticas.

Gênero com seis espécies ocorrendo no leste da Bolívia e estendendo-se até a Argentina e Brasil. No estado do Paraná ocorrem quatro espécies. Dentro do gênero, Lepismium lumbricoides é frequentemente confundida com espécies de Rhipsalis, esta dúvida é sanada ao se observar uma nítida escama triangular cobrindo as aréolas na primeira.

\section{Chave para identificação das espécies de Lepismium}

1. Segmentos caulinares com formato monomórfico cilíndricos 3. Lepismium lumbricoides

1'. Segmentos caulinares secundários ou com formato monomórfico alados.

2. Projeções das margens do caule com ápice agudo; segmentos caulinares com formato dimórficos, cilíndricos na base e alados na porção mediana e apical 2. Lepismium houlletianum

2'. Projeções das margens do caule com ápice arredondado; segmentos caulinares com formato monomórfico, alados.

3. Aréolas estéreis tomentosas; pericarpelo imerso no caule 1. Lepismium cruciforme

3'. Aréolas estéreis glabras a pubescentes; pericarpelo emerso do caule... 
6.1 Lepismium cruciforme (Vell.) Miq., Bull. Sci. Phys. Nat. Néerl. 1838: 49. $1838 . \quad$ Fig. 2e-f

Epífitas ou rupícolas até $3 \mathrm{~m}$ compr., reptantes no forófito ou pendentes. Caules esverdeados, ramificações subapicais ou laterais, 2-3-furcados, segmentos com formato monomórfico, 2-3-alados, alas contínuas, base aguda, ápice agudo, margens serreadas, ápice das projeções das margens arredondado, $70-500 \times 3,2-24 \times 0,7-2,2 \mathrm{~mm}$, nervura central 1,3-3,9 mm larg., crescimento indeterminado. Aréolas estéreis $0,3-1,3 \mathrm{~mm}$ larg., tomentosas com escama triangular, aréolas férteis 1,1-4,7 mm larg., lanosas com escama triangular, podários não desenvolvidos. Flores 1 por aréola, $8,3-13 \times 3,5-8,1 \mathrm{~mm}$, laterais, rotáceas; pericarpelos esverdeados, 1,4-2,3 $\times$ 1,1-2,9 mm, imersos no caule, globosos, glabros; segmentos externos do perianto $2-4$, alvos a rosados, $0,8-4,5 \times 0,6-3,6 \mathrm{~mm}$, eretos, triangulares a elípticos; segmentos internos do perianto 5-7, alvos a rosados, 4,4-9,4 × 1,3-4,5 $\mathrm{mm}$, eretos, estreito-elípticos a elípticos; estames 32-46, alvos, 2,4-7,1 mm compr.; estiletes 4,9-7,3 mm compr., lobos 3-4, 1,4-3,4 mm compr. Frutos magenta, avermelhados ou purpúreos, 4,8-15 × 4,2-10 mm, 4-costados. Sementes 12-37, castanhas, 1,2-1,6 $\times$ $0,6-0,9 \mathrm{~mm}$, elípticas.

Material selecionado: Braganey, 1.IV.2000, fr., $M$. Borgo 712 (UPCB). Curitiba, 25.IX.2000, fl., M.Borgo 835 (UPCB). Fênix, P.E.Vila Rica do Espirito Santo, 25.I.2000, fl., M.Borgo 1151 (UPCB). Fênix, Fazenda Cagibi, 18.II.1998, fr., S.M. Silva (UPCB 33173). Ponta Grossa, P.E. Vila Velha, 6.III.1996, fr., H.F. Oliveira 336 (UPCB). São Mateus do Sul, 7.I.1986, fl., R.M.Britez 289 (UPCB, MBM). Telêmaco Borba, 17.IX.2008, fl., M. Vallejos 15 (UPCB).

Lepismium cruciforme é encontrado como epífito ou rupícolo e geralmente reptante no forófito, ocorre em todas as formações vegetais presentes no Paraná. É reconhecido pelas projeções das margens do caule com ápice arredondado, aréolas estéreis tomentosas e pericarpelo imerso no caule. Quando plântula assemelha-se a Lepismium warmingianum, mas é distinto desta pelas aréolas estéreis tomentosas com tricomas em quantidade e comprimento superior que aqueles encontrados nas aréolas estéreis de $L$. warmingianum.

6.2 Lepismium houlletianum (Lem.) Barthlott, Bradleya 5: 99. $1987 . \quad$ Fig. 2g-h

Epífitas até $1 \mathrm{~m}$ compr., pendentes ou eretas. Caules esverdeados, ramificações subapicais ou laterais, 2-furcados, segmentos com formato dimórfico; segmentos primários cilíndricos, 120-130 $\times 2-3,7 \mathrm{~mm}$, crescimento indeterminado; segmentos secundários com base cilíndrica e região mediana e ápice alados, alas contínuas, base aguda a atenuada, ápice agudo, margens serreadas, ápice das projeções das margens agudo, $120-450 \times 15-68 \times 0,8-2,1$ $\mathrm{mm}$, nervura central $1,3-4 \mathrm{~mm}$ larg., crescimento indeterminado. Aréolas estéreis 0,3-0,7 mm larg., com escama triangular, aréolas férteis $0,6-1,8 \mathrm{~mm}$ larg., pubescentes com escama triangular, podários não desenvolvidos. Flores 1 por aréola, 14-19 × 11-20 $\mathrm{mm}$, laterais, rotáceas; pericarpelos esverdeados, 3,75,5 × 2,9-4,2 mm, emersosdo caule, 4-5-costados, glabros; segmentos externos do perianto $2-3$, alvos a esverdeados, $1-3,6 \times 1,2-3 \mathrm{~mm}$, eretos, triangulares a arredondados; segmentos internos do perianto 9-10, alvos, 4,6-14 × 3-3,7 mm, eretos, estreito-elípticos a oblanceolados; estames 24-37, alvos, 3,5-9,6 mm compr.; estiletes $6,7-11 \mathrm{~mm}$ compr., lobos 2-3, 1,7-3,4 mm compr. Frutos róseos, avermelhados ou purpúreos, 5,5-11 × 3-9,3 mm, globosos. Sementes 15-43, castanhas, 1-1,4×0,6-0,9 mm, elípticas.

Material selecionado: Cerro Azul, Rio Turvo, 19.VII.1984, fl., G. Hatschbach 48112 (UPCB, MBM). Curitiba, Pq. Barigui, 26.X.1995, fr., C. Kozera 13 (UPCB). Morretes, Serra da Graciosa, 11.VII.1996, fl., A.C. Cervi 6129 (UPCB). Pinhais, 18.VIII.1999, fl. e fr., M.P. Petean 64 (UPCB). Piraquara, 5.XI.2001, fr., $R$. Goldenberg 516 (UPCB). Ponta Grossa, Buraco do Padre, 17.XII.1995, fr., H.F. Oliveira 327 (UPCB). Telêmaco Borba, 31.VII.2008, fr., Urben Filho 13 (UPCB).

Lepismium houlletianum é caracterizado por segmentos do caule alados na porção mediana e apical, e cilíndricos, recoberto por periderme, na porção basal, além das projeções das margens das alas com ápice agudo. Lepismium houlletianum ocorre em todas as formações vegetais presentes no estado, porém em maior frequência nas áreas florestais.

\subsection{Lepismium lumbricoides (Lem.) Barthlott,} Bradleya 5: 99. $1987 . \quad$ Fig. 2i-k

Epífitas até $3 \mathrm{~m}$ compr., reptantes no forófito ou pendentes. Caules esverdeados, ramificações subapicais ou laterais, 2-3-furcados, segmentos com formato monomórfico, cilíndricos, 18-660 × 1,5-3,9 mm, crescimento indeterminado. Aréolas estéreis $0,3-0,8 \mathrm{~mm}$ larg., com escama triangular, aréolas férteis 1,9-12 mm larg., pubescentes com escama triangular, podários não desenvolvidos. Flores 1 por aréola, $12-16 \times 5,3-11 \mathrm{~mm}$, apicais, subapicais ou laterais, campanuladas; pericarpelos esverdeados, 3,5-4,5 × 2,1-2,8 mm, emersos do caule, piriformes, glabros; segmentos externos 
do perianto 4, alvos, 1-3,3 × 1-3,4 mm, eretos, triangulares a oblanceolados; segmentos internos do perianto 8-10, alvos, 4,6-11 × 1,3-8 mm, eretos, estreito-elípticos a oblanceolados; estames 18-33, alvos, 3,6-7,8 mm compr.; estiletes 6-8,3 mm compr., lobos 4, 1,3-22 mm compr. Frutos avermelhados ou vináceos, 6-7,9 × 5,3-7,2 mm, globosos a elípticos. Sementes 34-55, castanhas, 1,2-1,4 × 0,5-1,1 mm, elípticas.

Material selecionado: Araucária, REPAR, I.2001, fr., $R$. Kersten (UPCB 43485). Curitiba, Pq. Barigui, 9.X.1996, fl., C. Kozera 248 (UPCB). Foz do Iguaçu, Pq. Nacional do Iguaçu, 3.X.2006, fl., P.H. Labiak 3846 (UPCB). Ipiranga, 8.X.1969, fl., G. Hatschbach 22378 (MBM). Palmas, 18.X.2005, D. Liebsch 1064 (UPCB, HFC). Pinhão, Rio da Divisa, 28.XI.91, fr., F. Bonatto 16(MBM). Ponta Grossa, 23.X.2007, fr., Bonnet (UPCB 65146).

Lepismium lumbricoides é a única espécie do gênero com segmentos do caule completamente cilíndricos e, por muitas vezes, é confundida com espécies de Rhipsalis. Apesar disso, pode ser reconhecida pelo crescimento indeterminado do caule e pelas escamas triangulares persistentes e conspícuas que ocorrem sobre as aréolas estéreis. Ocorre em todas as formações florestais do estado.

\subsection{Lepismium warmingianum (K. Schum.)} Barthlott, Bradleya 5: 99. $1987 . \quad$ Fig. 21-m

Epífitas até $3 \mathrm{~m}$ compr., reptantes no forófito ou pendentes. Caules esverdeados, ramificações subapicais ou laterais, 2-(3)-furcados, segmentos com formato monomórfico, 2-3-alados, alas contínuas, base aguda, ápice agudo ou truncado, margens serreadas, ápice das projeções das margens arredondado, 70-410 × 2,8-12 $\times$ 0,8-1,6 $\mathrm{mm}$, nervura central 1,1-2,6 $\mathrm{mm}$ larg., crescimento indeterminado. Aréolas estéreis 0,3-1,3 mm larg., aréolas férteis 2,4-29 $\mathrm{mm}$ larg., aréolas estéreis e férteis glabras a pubescentes com escama triangular, podários não desenvolvidos. Flores 1 por aréola, 16-22 $\times$ 7-16 mm, laterais, campanuladas; pericarpelos esverdeados, 3,9-7,6 × 2,7-4 $\mathrm{mm}$, emersos do caule, 4-5-costados, glabros; segmentos externos do perianto 3-5, alvos, 1-7,2 × 1,3-6,4 $\mathrm{mm}$, eretos, arredondados a ovais; segmentos internos do perianto 8-12, alvos, 6-15 × 1,7-5,6 $\mathrm{mm}$, eretos, estreito-elípticos a oblanceolados; estames 25-37, alvos, 5,3-12 mm compr.; estiletes 7,2-12 mm compr., lobos 3-4, 2,3-3,2 $\mathrm{mm}$ compr. Frutos róseos ou purpúreos, 7,7-12 $\times$ 5,6-8,2 mm, 4-5-costados. Sementes 3-76 castanhas, 1,3-1,6 ×0,6-0,7 mm, elípticas.
Material selecionado: Curitiba, Jd. Botânico, 4.IX.2009, fr., J. Meirelles 414 (UPCB). Fênix, 17.IX.1996, fr., Mikich (UPCB 33172). Foz do Iguaçu, Pq. Nacional do Iguaçu, 19.X.1991, fl., A.C. Cervi, 3429 (UPCB). Ponta Grossa, Furnas Gêmeas, 28.I.1996, fr., H.F. Oliveira 323 (UPCB). Porto Amazonas, Ponte dos Arcos, 30.VIII.2004, fr., R.A. Kersten 932 (UPCB). São Mateus do Sul, 16.IX.1986, fr., W.S. Souza 302 (UPCB). Tibagi, Rio Tibagi, 9.X.2006, fl., A.Bonnet 780211 (UPCB).

Lepismium warmingianum possui projeções das margens do caule com ápice arredondado, aréolas estéreis glabras a pubescentes e o pericarpelo emerso do caule. Ocorre em todas as formações florestais do estado. Assemelha-se à Lepismium cruciforme quando este é jovem, porém este apresenta suas aréolas estéreis tomentosas e o pericarpelo imerso no caule.

7. Opuntia Mill., Gard. Dict. Abr. (ed. 4). 1754. 7.1 Opuntia monacantha Haw., Suppl. pl. succ., Suppl. 81. 1819.

Fig. 1g-i

Terrícolas até $4 \mathrm{~m}$ compr., eretas. Caules castanhos ou esverdeados, ramificações subapicais ou laterais, 2-furcados, segmentos com formato monomórfico, aplanados, lanceolados a ovais, base aguda, ápice arredondado, margens lisas, 14-54 cm × 13-20 cm × 11-13 mm, crescimento determinado. Aréolas estéreis 1,8-5,2 mm larg., tomentosas e/ou com folhas cônicas, 2,5-3,2 $\times$ 1,8-2 mm, vináceas ou 1-2 espinhos, 4-43 mm compr., acinzentados, ápice castanho, aréolas férteis 8,3-35 mm larg., lanosas com 1 ou 2 espinhos, podários não desenvolvidos. Flores 1 por aréola, 7-11 × 7-8 cm, apicais, subapicais ou laterais, rotáceas; pericarpelos esverdeados, 8-36 × 7-11 mm, emersos do caule, piriformes, cobertos de aréolas; segmentos externos do perianto 9-10, vináceos, 4,8-9,5 × 9,2-13,4 mm, eretos a patentes, triangulares a arredondados; segmentos internos do perianto 15-17, vináceos no centro com bordas amarelas até totalmente amarelos, 10-18 × 4-6 mm, patentes, obovais com ápices mucronados a truncados; estames alvos com anteras amarelas, 13,7-17,5 mm compr.; estiletes 15-17 mm compr., 7-8 lobos, 6,8-7,5 $\mathrm{mm}$ compr. Frutos esverdeados a vináceos, 6-10 $\times 3,5-4 \mathrm{~cm}$, piriformes. Sementes castanhas, 1,9-2,5 × 1,8-2,1 mm, elípticas.

Material selecionado: Balsa Nova, 31.X.1985, fl., J.M. Silva 26 (MBM). Curitiba, 2.XI.2011, fl. e fr., A.Soller 160 (UPCB). Cerro Azul, 7.XII.1994, fl., G. Hatschbach 61540 (MBM). Paranaguá, 1.VI.1962, fl., G. Hatschbach 9181 (MBM). 
Opuntia monacantha é caracterizada por possuir todos os segmentos caulinares aplanados e flores com segmentos petalóides externos vináceos. Ocorre na região da Floresta Ombrófila Densa no litoral do Paraná. É distinta de Brasiliopuntia brasiliensis pois esta possui os segmentos caulinares primários cilíndricos, flores amareladas e atinge até $20 \mathrm{~m}$ de compr.

8. Parodia Speg., Anales Soc. Ci. Argent. 96: 70. 1923. 8.1 Parodiacarambeiensis (Buining \& Brederoo) Hofacker, Cactaceae Consensus Init. 6: 11. 1998.

Fig. $1 \mathrm{j}$

Rupícolas até $20 \mathrm{~cm}$ compr., globosas. Caules esverdeados, não ramificados, com formato monomórfico, costelados, 10-13 costelas, 4,3-12 mm larg. × 6,6-13 mm esp., 44-130 mm diâm., crescimento determinado. Aréolas estéreis 1,7-9,9 $\mathrm{mm}$ larg., aréolas férteis 2,5-5 mm larg., ambas lanosas com (8)-10-11-(13) espinhos castanhos, 3,4-23 mm compr., podários não desenvolvidos. Flores 1-(2) por aréola, $19-31 \mathrm{~mm} \times 14-25 \mathrm{~cm}$, apicais, rotáceas; pericarpelos esverdeados, 3,7-8,8 $\times 5-7,7 \mathrm{~mm}$, emersos do caule, piriformes, cobertos por aréolas estéreis; segmentos externos do perianto amarelados, 5,4-17,7 × 1,5-8,8 mm, eretos, estreitoelípticos; segmentos internos do perianto amarelados, 11-28 × 1,4-2,3 mm, eretos, estreito-elípticos; estames amarelos, 6,2-17 cm compr.; estiletes amarelos e estigmas róseos, $10-15 \mathrm{~cm}$ compr. Frutos vináceos, ca. $8 \times 6 \mathrm{~mm}$, elípticos. Sementes negras, 1,8-2,1 × 1,5-1,7 mm, globosas com ápice truncado. Material selecionado: Balsa Nova, Ponte do Arcos, 6.VII.2005, fl., C. Kozera 2675 (UPCB). Campo Mourão, 14.X.2008, fl., M.G. Caxambu 2349 (HCF). Ponta Grossa, P.E. Vila Velha, 16.IX.1997, fl., A.C.Cervi 6333 (UPCB). Turvo, 18.X.2009, fl., M.G. Caxambu 2847 (HCF).

Parodia carambeiensis é a única espécie de Cactaceae endêmica do Paraná. É caracterizada pelo caule globoso, estilete amarelo, estigma fortemente róseo e é encontrada nas estepes do estado. Difere de Parodia ottonis Haw., ocorrente no Rio Grande do Sul, pois esta apresenta o estilete alvo e o estigma amarelado.

\section{Pereskia Mill., Gard. Dict. Abr. Ed. 4. 1754.} 9.1 Pereskia aculeata Mill. Gard. Dict., ed. 8.1768 .

Fig. 1k-1

Terrícolas até $30 \mathrm{~m}$ compr., escandentes ou eretas. Caules castanhos a esverdeados, ramificações subapicais ou laterais, 2-furcados, segmentos com formato monomórfico, cilíndrico, 0,3-3,9 mm larg., crescimento indeterminado.
Aréolas estéreis 1-2,5 mm larg., lanosas com escama e/ou folha e/ou espinhos, folhas regulares presentes, verdes, 27-99 × 4,4-38 mm, estreitoelípticas a ovais, ápice atenuado a agudo, base arredondada a aguda, lâmina glabra, aréolas férteis 0,9-4,2 mm larg., pubescentes e/ou espinhos, podários não desenvolvidos; inflorescências terminais ou laterais, racemosas ou paniculadas. Flores 1 por aréola, $28-34 \times 36-47 \mathrm{~mm}$, apicais, rotáceas; pericarpelos esverdeados, 2-6 × 3,7-7,6 $\mathrm{mm}$, emersos do caule, globosos, cobertos por aréolas férteis com folha ausente ou com uma, 3,7-26 × 1,5-7,7 mm, e/ou 1-3 espinhos, 0,4-9,2 mm compr.; segmentos externos do perianto $7-8$, alvos, 1,6-5,3 × 1,1-2,2 mm, reflexos, triangulares; segmentos internos do perianto 10-13, alvos, $18-32 \times 3,7-9 \mathrm{~mm}$, patentes, estreito-elípticos a lanceolados; estames 75-130, alvos, 8,6-16 mm compr.; estiletes $12-14 \mathrm{~mm}$ compr., $4-5$ lobos, $4,8-5,8 \mathrm{~mm}$ compr. Frutos alaranjados, $0,7-17 \times$ $0,5-12 \mathrm{~mm}$, globosos. Sementes $2-6$, castanhas, 3,5-3,8 $\mathrm{mm} \times 3,5-4,7 \mathrm{~mm}$, discóides.

Material selecionado: Capitão Leônidas Marques, Rio Iguaçu, 21.III.1993; fl., S.M. Silva (UPCB 20573). Diamante do Norte, E.E. Caiuá, 18.V.2006, fr., D.N.M. Zeiden 15 (HUEM). Fênix, P.E. Vila Rica, 18.II.1998, fl., S.M. Silva (UPCB 33167). Ilha de Currais, 4.II.1997, fl., C.Jaster (UPCB 29621). Sapopema, Salto das Orquídeas, 1997, fl., M.R.C. Paiva (HUEM 24946).

Pereskia aculeta é caracterizada pelo hábito escandente e crescimento indeterminado, em muitas ocasiões tornando o ápice da planta pendente. Ocorre na Floresta Estacional Semidecidual do Paraná e o estado representa o limite sul de ocorrência da espécie no Brasil. Difere de Pereskia grandifolia, uma espécie arbustiva ou arbórea cultivada no estado, pois esta tem flores róseas e frutos piriformes a turbinados.

10. Praecereus Buxb., Beitr. Biol. Pflanzen 44(2): 273. 1968.

10.1 Praecereus euchlorus (F.A.C. Weber) N.P. Taylor, Cactaceae Consensus Init. 3:10. 1997.

Fig. $1 \mathrm{~m}-\mathrm{o}$

Terrícolas até $4 \mathrm{~m}$ compr., eretas. Caules esverdeados, ramificações basais, segmentos com formato monomórfico, costelados, 7-9 costelas, 7-9 mm larg. × 4-9 mm esp., 37-45 mm diâm., crescimento indeterminado. Aréolas estéreis 3-5 $\mathrm{mm}$ larg., aréolas férteis 4-6 $\mathrm{mm}$ larg., aréolas estéreis e férteis lanosas com 3-5-6-(7) espinhos castanhos com ápices negros, 2-40 mm compr., podários não desenvolvidos. Flores 1 por aréola, $9-10 \times 3,5-4,5 \mathrm{~cm}$, laterais, infundibuliformes; 
pericarpelos esverdeados, 53-74 × 7-46 mm, emersos do caule, piriformes, cobertos por escamas; segmentos externos do perianto alvos a esverdeados com extremidades vináceas, 6-8 8 5-7 mm, eretos, triangulares a ovais; segmentos internos do perianto alvos, 13-47 × 8,3-9 mm, eretos, estreito-elípticos; estames alvos, 23-27 cm compr.; estiletes 6-7 cm compr. Frutos esverdeados a avermelhados, ca. 4,5 $\times 3,5 \mathrm{~mm}$, globosos elípticos. Sementes não vistas. Material selecionado: Guaíra, Sete Quedas, 22.IV.1968, fl., G. Hatschbach 19098 (MBM). Porto Rico, Rio Paraná, 9.XI.1992, fl., M.C. Souza-Steuvaux 293 (HUEM). São Pedro do Paraná, Rio Paraná, 5.X.2006, fl., K.K. Kita 1389 (HUEM).

Praecereus euchlorus é um cacto colunar de porte arbustivo, ramificado apenas da base dos segmentos caulinares, alcançando até $4 \mathrm{~m}$ compr. $\times$ 37-45 mm diâm. se diferenciando de Cereus hildmannianusque atinge $15 \mathrm{~m}$ compr. $\times$ 58-165 mm diâm. e possui ramificações ao longo dos segmentos caulinares. Ocorre na parte central e oeste do Paraná na Floresta Estacional Semidecidual, geralmente nas margens dos rios.
11. Rhipsalis Gaertn., Fruct. sem. pl. 1: 137. 1788. Plantas arbustivas, epífitas ou rupícolas, 0,3-5 m compr., pendentes ou eretas, ramificação apical, subapical ou lateral. Caule segmentado, monomórfico ou dimórfico, cilíndrico, 3-60 $\times$ 0,1-3 cm ou 2-(3)-(4)-(5)-alado, 4-60 × 2-12 $\mathrm{cm}$, ou angulado, com crescimento determinado. Folhas ausentes. Aréolas dispostas nas margens das alas ou ao redor do caule nas espécies cilíndricas, glabras, pilosas, pubescentes, velutinas ou lanosas e escamas persistentes ou decíduas; espinhos 0-22, aciculares. Flores 0,6$1,7 \mathrm{~cm}$ compr., laterais, subapicais ou apicais, alvas, amareladas ou róseas; pericarpelo glabro ou com aréolas; antese diurna. Frutos globosos, 0,2-2 cm compr., alvos, róseos, vermelhos, alaranjados ou purpúreos. Sementes castanhas ou negras, lisas, ovais, curvas, ou hemisféricas.

Gênero com 38 espécies com distribuição nas Américas e uma espécie distribuída também na África, ilhas do Oceano Índico e Leste do SriLanka. No estado do Paraná, ocorrem 11 espécies.

\section{Chave para identificação das espécies de Rhipsalis}

1. Segmentos caulinares alados ou angulados.

2. Segmentos angulados; rupícola

3. Rhipsalis dissimilis

2'. Segmentos alados; epífita.

3. Segmentos lineares; 0,26-1 cm larg.

4. Alas bifurcadas na aréola

8. Rhipsalis paradoxa

4'. Alas contínuas 11. Rhipsalis trigona

3'. Segmentos estreito-elípticos, elípticos ou ovais; 1,3-10 cm larg.

5. Ápice dos segmentos caulinares agudos a cuneados; frutos ovais

4. Rhipsalis elliptica

5'. Ápice dos segmentos caulinares arredondados a truncados; frutos globosos 7. Rhipsalis pachyptera

1'. Segmentos caulinares cilíndricos.

6. Pericarpelo imerso no caule; podário desenvolvido

5. Rhipsalis floccosa

6'. Pericarpelo emerso do caule; podário não desenvolvido.

7. Aréolas pubescentes ou velutinas.

8. Segmentos caulinares com tamanhos dimórficos; aréolas pubescentes; corola campanulada; frutos alvos 2. Rhipsalis cereuscula

8'. Segmentos caulinares com tamanhos monomórficos; aréolas velutinas; corola rotácea; frutos róseos ou vináceos 9. Rhipsalis pilocarpa

7'. Aréolas com escamas.

9. Corola campanulada; estames alvos com base rósea; frutos alaranjados

9'. Corola rotácea; estames alvos; frutos alvos,purpúreos ou róseos.

10. Segmentos caulinares $13-21 \mathrm{~cm}$ compr.; flores $6,8-16 \mathrm{~mm}$ compr. 6. Rhipsalis grandiflora

10'. Segmentos caulinares primários $38-120 \mathrm{~cm}$ compr.; flores $5,8-6,3 \mathrm{~mm}$ compr. ... 10. Rhipsalis teres 
11.1 Rhipsalis campos-portoana Loefgr., Arch. Jard. Bot. Rio de Janeiro 2:35. $1918 . \quad$ Fig. 3a

Epífitas até $3 \mathrm{~m}$ compr., pendentes. Caules esverdeados, ramificações apicais, subapicais ou raramente laterais, 2-3-(4)-furcados, segmentos com comprimento dimórfico e formato monomórfico, cilíndricos; segmentos primários $22-430 \times 1,1-2,6 \mathrm{~mm}$, crescimento indeterminado; segmentos secundários 8,4-64 × 0,5-1,9 mm, crescimento determinado. Aréolas estéreis $0,3-0,8 \mathrm{~mm}$ larg., aréolas férteis $0,8-1,5$ $\mathrm{mm}$ larg., aréolas estéreis e férteis com escamas filiformes, podários não desenvolvidos. Flores 1-(2)-(3) por aréola, 12-16 × 6,8-11 mm, apicais ou subapicais, campanuladas; pericarpelos esverdeados a amarelados, 3,5-4,2 × 2,6-3,7 $\mathrm{mm}$, emersos do caule, globosos a piriformes, glabros; segmentos externos do perianto 2-4, alvos ou esverdeados, $0,5-4,3 \times 0,6-2,8 \mathrm{~mm}$, eretos, triangulares; segmentos internos do perianto alvos 8-12, 4,7-11 × 1,5-3,7 mm, eretos, estreitoelípticos a oblanceolados; estames 22-32, alvos com bases róseas, 2,3-7,6 $\mathrm{mm}$ compr.; estiletes 5,2-6,5 mm compr., lobos 3-4, 2-3 mm compr. Frutos alaranjados, 5,8-8 × 5,6-7,6 mm, globosos a elípticos. Sementes $2-15$, castanhas, 1,5-1,8 $\times$ $0,7-0,8 \mathrm{~mm}$, reniformes.

Material selecionado: Bocaiúva do Sul, Rio Capivari, 9.IX.1994, fl., J.M. Silva 1389 (MBM). Curitiba, 16.XI.2010, A. Soller 73 (UPCB). Guaraqueçaba, 9.VIII.1967, fl., G. Hatschbach 16890 (MBM). Guaratuba, Rio Itararé, 19.II.1998, fr., E. Barbosa 2271 (MBM). Morretes, 29.V.1985, fr., J.Cordeiro 57 (MBM); 28.VIII.1986, f1., J.M. Silva 158 (MBM). São José dos Pinhais, 29.IV.2005, fr., C. Costa 4 (MBM). São Mateus do Sul,20.VII.1986, fl., W.S. Souza 225 (MBM).

Rhipsalis campos-portoana é reconhecida pelos seus segmentos caulinares primários longos, 2,2-43 cm compr., e secundários mais curtos, 0,84-6,4 cm, sempre ramificados nas aréolas apicais em dois ou mais e em ângulo reto. Ocorre em Floresta Ombrófila Densa e Mista. Alguns exemplares previamente identificados nos herbários como Rhipsalis burchelli Britton \& Rose e Rhipsalis juengeri Barthlott \&N. P. Taylor foram considerados pertencentes a $R$. campos-portoana neste trabalho.

11.2 Rhipsalis cereuscula Haw., Philos. Mag. Ann. Chem. 7:112. $1830 . \quad$ Fig. 3b-c

Epífitas até 1,5 m compr., pendentes. Caules esverdeados, ramificações apicais, 2-3(4)-(5)-furcados, segmentos caulinares com camprimento dimórfico e formato monomórfico, cilíndricos; segmentos primários 26,7-270 × 1,1$5,8 \mathrm{~mm}$, crescimento indeterminado; segmentos secundários 5-61 × 3,4-9 $\mathrm{mm}$, crescimento determinado. Aréolas estéreis 0,3-0,6 mm larg., aréolas férteis 0,7-2,3 mm larg., aréolas estéreis e férteis pubescentes, podários não desenvolvidos. Flores 1-2 por aréola, 11,6-13,6 × 2,2-9,2 mm, apicais, campanuladas; pericarpelos alvos a amarelados, 3,2-4,3 × 2,3-4 mm, emersos do caule, hemiglobosos, cobertos por aréolas; segmentos externos do perianto $3-4$, alvos, $0,7-4,9 \times 0,9-2,6$ $\mathrm{mm}$, eretos, triangulares; segmentos internos do perianto 8-12, alvos, 4,2-11 × 1,3-3,1 mm, eretos, estreito-elípticos a oblanceolados; estames 45-70, alvos com bases avermelhadas, 1,9-7,8 mm compr.; estiletes 7-9,6 mm compr., lobos 3-4, 1,9-2,6 $\mathrm{mm}$ compr. Frutos alvos, 5,5-6,3 × 5,5-5,7 mm, globosos. Sementes 1-64, castanhas, 1,1-1,5 × $0,6-0,7 \mathrm{~mm}$, elípticas.

Material selecionado: Campo Mourão, Rio Mourão, 26.VIII.2001, fl., E. Barbosa 72337 (MBM). Coronel Vívida, 27.VIII.1975, fl., R. Kummrow 925 (MBM). Foz do Iguaçu, Pq. Nacional do Iguaçu, 21.VIII.1998, fl., S.R. Ziller 1677 (MBM). Pinhão, Rio Verde, 15.I.1992, fr., A.J. Kostin 73 (MBM). Ponta Grossa, P.E. Vila Velha, 8.IX.1974, fl., L.F. Ferreira 66 (MBM). Tibagi, 1.X.1989, fl., J.M. Silva 644 (MBM). Santo Antônio, 24.X.1969, fr., G. Hatschbach 22636 (MBM). São Pedro do Ivai, 18.X.2003, fr., O.S. Ribas 5656 (MBM). Três Barras, 2.IX.1999, W. Maschio 3046 (MBM).

Rhipsalis cereuscula é reconhecida pelos longos segmentos primários com crescimento indeterminado, 26,7-270 $\mathrm{mm}$, e segmentos secundários bem curtos, 5-61 mm,não obrigatoriamente multifurcados. Possui ampla distribuição no Paraná ocorrendo na Floresta Ombrófila Mista e Estacional Semidecidual, Estepe e na Savana.

11.3 Rhipsalis dissimilis K. Schum., in Martius, Fl. bras. 4(2): 286. $1890 . \quad$ Fig. 3d

Rupícolas até $70 \mathrm{~cm}$ compr., eretas. Caules amarelados a esverdeados, ramificações apicais, raramente subapicais ou laterais, 2-3-(4)(6)-furcados, segmentos monomórficos, 6-9 angulados, 13-116 × 4,5-11 mm, ângulos 1-2,5 $\mathrm{mm}$ larg., crescimento determinado. Aréolas estéreis 1-3,6 mm larg., pubescentes e nos ramos jovens com espinhos, aréolas férteis 2,9-7,8 mm larg., lanosas, podários desenvolvidos. Flores 1 por aréola, 8,9-13,6 × 10-15,3 mm, apicais, subapicais ou laterais, rotáceas; pericarpelos róseos, 2,6-3,5 $\times$ 3-4,9 mm, imersos no caule, piriformes, glabros; 


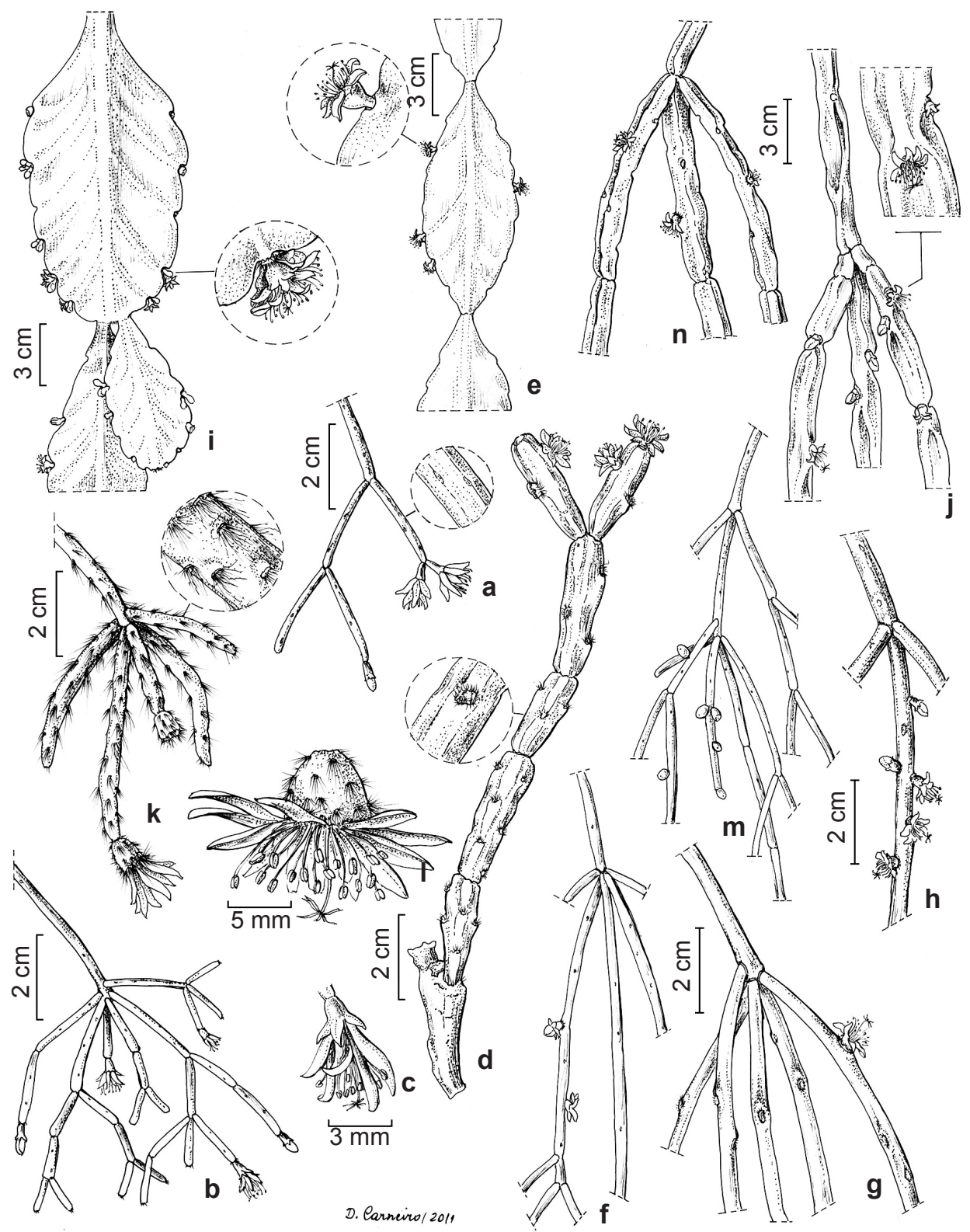

Figura 3 - a. Rhipsalis campos-portoana Loefgr. - ramo com flor e destaque da aréola estéril (Hatschbach 16890). b-c. Rhipsalis cereuscula Haw. - b. ramo com botão e flor; c. flor campanulada (Kersten 931). d. Rhipsalis dissimilis K. Schum. - ramo com flor e destaque da aréola fértil (Michelon 837). e. Rhipsalis elliptica G. Lindb. ex K. Schum. - ramo com destaque da flor (Hatschbach 52139). f-g. Rhipsalis floccosa Salm-Dyck ex Pfeiff. - f. ramo com botão e flor (Soller 142); g. ramo com flor (Soller 75). h. Rhipsalis grandiflora Haw. - ramo com flor (Soller 132). i. Rhipsalis pachyptera Pfeiff. - ramo com destaque da flor (Kersten 619). j. Rhipsalis paradoxa Salm-Dyck - ramo com destaque da flor (Soller 155). k-1. Rhipsalis pilocarpa Loefgr. - k. ramo com flor e destaque da aréola estéril; 1. flor rotácea.(Cordeiro 100). m. Rhipsalis teres Steud. - ramo com fruto (Meyer 716). n. Rhipsalis trigona Pfeiff. - ramo com flor (Hatschbach 53166). Figure 3 - a. Rhipsalis campos-portoana Loefgr. - branch with flower and sterile areole (Hatschbach 16890). b-c. Rhipsalis cereuscula Haw. - b. branch with flower and flower bud; c. campanulate flower (Kersten 931). d. Rhipsalis dissimilis K. Schum. - branch with flower and fertile areole (Michelon 837). e. Rhipsalis elliptica G. Lindb. ex K. Schum. - branch with flower (Hatschbach 52139). f-g. Rhipsalis floccosa Salm-Dyck ex Pfeiff. -f. branch with flower and flower bud (Soller 142); g. branch with flower (Soller 75). h. Rhipsalis grandiflora Haw. - branch with flower (Soller 132). i. Rhipsalis pachyptera Pfeiff. - branch with flower (Kersten 619). J. Rhipsalis paradoxa Salm-Dyck - branch with flower (Soller 155). k-1. Rhipsalis pilocarpa Loefgr. - k. Branch with flower and sterile areole; 1. rotate flower (Cordeiro 100). m. Rhipsalis teres Steud. - branch with fruit (Meyer 716). n. Rhipsalis trigona Pfeiff. - branch with flower (Hatschbach 53166). 
segmentos externos do perianto 2-6, amarelados, 3,4-7,9 × 2-6 mm, reflexos, triangulares; segmentos internos do perianto 8-12, amarelados, 6,3-12 × 2,4-6,2 mm, patentes, ovais a elípticos; estames 83-107, alvos, 1,9-9,3 mm compr.; estiletes 5,6-7,9 mm compr., lobos 4-5, 2-2,8 mm compr. Frutos róseos ou vináceos, com as extremidades superiores mais escuras, 5,7-8,3 × 8,1-9,8 mm, globosos. Sementes 9-26, castanhas, 1,6-1,7 ×0,8 $\mathrm{mm}$, elípticas.

Material selecionado: Castro, Rio São João, 3.X.1964, fl., G. Hatschbach 11670 (MBM). Cerro Azul,18. VII.1964, fl., G. Hatschbach 11326 (MBM). Palmeira, 1.IX.1999, fl., S.R. Ziller 1854 (MBM). Ponta Grossa, P.E. Vila Velha, 17.XI.1995, fl. e fr., H.F. Oliveira 322 (UPCB). Tibagi, P.E. Guartelá, 12.VII.2010, fl., $C$. Michelon 837 (UPCB); P.E. Guartelá, 31.I.11, fr., $A$. Soller 84 (UPCB).

Rhipsalis dissimilis é a única espécie de Rhipsalis rupícola do Paraná, geralmente encontrada em regiões expostas a fortes correntes de vento, principalmente, nos afloramentos de arenito das estepes do estado. Possui hábito ereto e o comprimento máximo encontrado foi de $70 \mathrm{~cm}$.

11.4 Rhipsalis elliptica G. Lindb. ex. K. Schum., in Mart., Fl. bras. 4(2): 293. 1890.

Fig. 3e

Epífitas até $2 \mathrm{~m}$ compr., pendentes. Caules esverdeados, ramificações apicais, subapicais ou laterais, 2-furcados, segmentos monomórficos, alados, 2-(3) alas, alas contínuas, estreito elípticos a elípticos, base aguda a cuneada, ápice agudo a cuneado, margens crenadas, crenas arredondadas, $48-200 \times 13-86 \times 0,8-3,8 \mathrm{~mm}$, nervura central 3,17,7 mm larg., crescimento determinado. Aréolas estéreis 0,5-1,2 mm larg., aréolas férteis 0,7-3,7 $\mathrm{mm}$ larg., aréolas estéreis e férteis pubescentes, podários não desenvolvidos. Flores 1-(2) por aréola, 8,3-12 × 5,6-17 mm, laterais, rotáceas; pericarpelos alvos ou róseos, 2,8-4,6 × 2,6-4,1 mm, emersos do caule, globosos, glabros; segmentos externos do perianto 2-5, amarelados, 0,4-3,3 $\times$ 1-4,7 mm, eretos, triangulares a obovados; segmentos internos do perianto 5-7, amarelados, 3,9-8,5 × 1,7-4 mm, eretos, oblanceolados a obovados; estames 66-98, alvos, 1,9-6,4 mm compr.; estiletes 3,7-5,7 mm compr., 3-5 lobos, 2,3-2,6 mm compr. Frutos purpúreos, 4,7-9,7 $\times$ 4,1-8,7 mm, elípticos. Sementes 14-59, castanhas, $1,2-1,5 \times 0,8 \mathrm{~mm}$, elípticas.

Material selecionado: Antonina, Rio Pequeno, 12.I.1974, fr., G. Hatschbach 33662 (MBM). Bocaiúva do Sul, 8.VI.1988, fl., G Hatschbach 52139 (MBM). Campina
Grande do Sul, Rio Capivari, 6.V.1986, fl., R. Kummrow 2749 (MBM). Contrafortes Serra Capivary Grande, 1.IV.1962, fl., G. Hatschbach 9105 (MBM). Guaraqueçaba, 12.VI.2007, fl., C.B. Poliquesi, 715 (MBM); P.E. Pico do Marumbi, 25.IV.1999, fl., M.P. Petean 41 (MBM). Ribeirão do Cedro, 18.II.1962, fl., G. Hatschbach 9056 (MBM). Tagaçaba, 8.V.1985, fl., G. Hatschabach 49349.

Rhipsalis elliptica assemelha-se a Rhipsalis pachyptera, da qual pode ser distinguida pelo ápice dos segmentos caulinares, agudos a cuneados, enquanto em $R$. pachyptera estes são arredondados a truncados. As aréolas férteis em $R$. pachyptera são, em sua maioria, muito maiores que as aréolas de $R$. elliptica. É encontrada no Paraná em Floresta Ombrófila Densa e Mista.

11.5 Rhipsalis floccosa Salm-Dyck ex Pfeiff., Enum. Diagn. Cact. 134. $1837 . \quad$ Fig. 3f-g

Epífitas até $2 \mathrm{~m}$ compr., pendentes ou eretas. Caules amarelados ou esverdeados, ramificações apicais, raramente subapicais ou laterais, 2-34-5-(6)-(7) furcados, segmentos monomórficos, cilíndricos, 55-220 × 0,7-6,6 mm, crescimento determinado. Aréolas estéreis 0,9-2,3 mm larg., glabras ou com escamas filiformes e/ou espinhos, aréolas férteis 1,8-6,3 mm larg., lanosas, podários desenvolvidos. Flores 1 por aréola, 7,1-12 × 7,8-15 $\mathrm{mm}$, apicais, subapicais ou laterais, rotáceas; pericarpelos amarelados ou alvos, 1,7-3,1 $\times$ 3-4,3 mm, imersos no caule, piriformes, glabros; segmentos externos do perianto 4-5, alvos com extremidades róseas a amarelados, 2,1-5,3 $\times$ 2,3-4,2 mm, patentes a reflexos, triangulares a obovados; segmentos internos do perianto 6-10, alvos a amarelados, 6-9,5 × 1,5-4,5 mm, patentes a eretos, lineares a oblanceolados; estames 78-99, alvos, 1,7-8,4 mm; estiletes 5,3-6,4 mm compr., 4-5 lobos, 1,3-2,2 mm compr. Frutos alvos a vináceos com a extremidade superior mais escura, 3,6-6 × 3,6-6,8 mm, globosos. Sementes 14-36, castanhas, $1,3-1,8 \times 0,6-0,8 \mathrm{~mm}$, elípticas com ápices assimétricos.

Material selecionado: Balsa Nova, Serra São Luiz, 21.X.1998, fl., E. Barbosa 141 (MBM). Cerro Azul, P.E. Campinhos, 29.I.2011, fr., A. Soller 76(UPCB). Curitiba, Pq. Barigui, 27.I.2011, fr., A. Soller 86 (UPCB). Foz do Iguaçu, 23.IX.1996, fl., G. Hatschbach 65316 (MBM). Palmeira, 22.IX.1982, fl., G. Hatschbach 45440 (MBM). Ponta Grossa, P.E. Vila Velha, 23.II.2011, fr., A. Soller 36 (MBM). São José dos Pinhais, 27.IX.1997, fl., J.M. Silva 2010 (MBM). Telêmaco Borba, 8.X.2011, fl., C. Michelon 1177 (UPCB). Tibagi, P.E. Guartelá, 31.I.2011, fr., A.Soller 85 (UPCB). Tomazina, 16.X.1997, fl., G. Hatschbach 67139 (MBM). 
Rhipsalis floccosa apresenta dois padrões morfológicos, sendo um em plantas que ocorrem geralmente em locais ensolarados, com crescimento inicial ereto, podários bem desenvolvidos, flores amareladas e frutos fortemente vináceos, enquanto que o outro ocorre em locais sombreados, cujas plantas possuem caule mais delgado, totalmente pendente, podários pouco desenvolvidos, flores alvas, frutos alvos. Além disso, uma grande variação foi encontrada no padrão de ramificação desta espécie nas populações do Paraná. Diversos indivíduos apresentaram ramos com segmentos caulinares ramificados na posição subapical ou até mesmo lateral, sendo que o padrão comum de ramificação descrito para esta espécie em outras localidades é apenas o apical (Barthlott \& Taylor 2005). O Paraná é o centro de endemismo do chamado "Grupo Rhipsalis floccosa" que é composto por Rhipsalis dissimilis, Rhipsalis trigona e Rhipsalis floccosa (Barthlott \& Taylor 1995), o que explica as grandes variações de $R$. floccosa encontradas no presente trabalho. Rhipsalis floccosaocorre em todas as formações do estado. Alguns exemplares previamente identificados como Rhipsalis puniceodiscus G.Lindb. foram atribuídos a $R$. floccosa.

11.6 Rhipsalis grandiflora Haw., Suppl. Pl. Succ. 83. 1819.

Fig. 3h

Epífitas até 2,5 m compr., pendentes. Caules esverdeados, ramificações apicais ou subapicais, 2-3-4-(7)-furcados, segmentos monomórficos, cilíndricos; segmentos primários $13-21 \mathrm{~cm} \times$ 2,6-17 mm, crescimento determinado; segmentos secundários $42-200 \times 2-17 \mathrm{~mm}$, crescimento determinado. Aréolas estéreis 0,4-0,9 mm larg., aréolas férteis $0,5-4 \mathrm{~mm}$ larg., aréolas estéreis e férteis com escamas filiformes, podários não desenvolvidos. Flores 1 por aréola, 6,8-16 $\times$ 4,6-9,2 $\mathrm{mm}$, laterais ou subapicais, rotáceas; pericarpelos amarelados, 2,3-2,9 × 2,6-5,2 $\mathrm{mm}$, emersos do caule, globosos, glabros; segmentos externos do perianto 3-5, alvos, $0,7-3,5 \times 0,8-4,4 \mathrm{~mm}$, reflexos, triangulares; segmentos internos do perianto $4-10$, alvos, $2,7-14 \times 1,2-5,1 \mathrm{~mm}$, eretos, elípticos a estreitoelípticos; estames 50-125, alvos, 1,2-12 mm compr.; estiletes $2,1-5,9 \mathrm{~mm}$ compr., $4-5$ lobos, 1,3-2,3 mm compr. Frutos alvos, purpúreos ou róseos, 3,4-7,6 × 3,7-7,1 mm, globosos. Sementes 17-55, castanhas ou negras, $0,8-1,1 \times$ $0,6-0,8 \mathrm{~mm}$, elípticas.
Material selecionado: Guaraqueçaba,26.IX.2002, fl., G. Hatschbach, 73844 (MBM). Guaratuba, 6.V.1999, fr., M. Borgo 272 (UPCB). Paranaguá, Ilha do Mel, 28.VIII.1987, fl., W.S. Souza 1766 (MBM). Pontal do Sul, 11.X.1999, fr., A. Dunaiski Jr. 1324 (UPCB).

Rhipsalis grandiflora é reconhecida pelo caule geralmente espesso e longo com ramificação apical e suas flores rotáceas também se destacam pelo seu tamanho maior em relação às outras espécies de Rhipsalis. É encontrada em Floresta Ombrófila Densa no litoral do Paraná.

11.7 Rhipsalis pachyptera Pfeiff., Enum. Diagn. Cact. 132. 1837.

Fig. 3i

Epífitas até $3 \mathrm{~m}$ compr., pendentes. Caules esverdeados, ramificações apicais, 2(3)-furcados, segmentos monomórficos, alados, 2-(3)-(4)-(5) alas, alas contínuas, ovais a elípticos, base cuneada, ápice arredondado a truncado, margens crenadas, crenas arredondadas, 96-240 × 14-100 × 0,6-3,4 mm, nervura central 4-13 mm larg., determinados. Aréolas estéreis 1,2-4,8 mm larg., aréolas férteis 1,8-7,8 mm larg., aréolas estéreis e férteis pubescentes, podários não desenvolvidos. Flores 1-2-3-(4)(5)-(7)-(15) por aréola, 12-14 × 3,4-17 mm, laterais, rotáceas; pericarpelos esverdeados a amarelados, 2,6-3,6 × 3,5-4,7 $\mathrm{mm}$, emersos do caule, campanulados, glabros; segmentos externos do perianto $3-5$, amarelados, $0,8-5,8$ $\times 2,5-5,5 \mathrm{~mm}$, eretos, triangulares; segmentos internos do perianto $6-10$, amarelados, 5,8-12 $\times 1,6-5 \mathrm{~mm}$, eretos, oblanceolados; estames 104-172, alvos, 1,9-9,4 mm; estiletes 4-8,3 mm compr., (4)-7 lobos, 1,4-3,1 mm compr. Frutos alvos a avermelhados, 4,8-8,7 × 3,8-7 mm, globosos. Sementes 5-85, castanhas ou negras, $0,9-1,4 \times 0,6-0,8 \mathrm{~mm}$, elípticas.

Material selecionado: Antonina, Mangue Maior Santo, 28.IV.1983, fl., G. Hatschbach 46275 (MBM). Guaraqueçaba, 14.IV.2003, fl., M. Borgo (323204 MBM). Guarapuava, 13.IV.1967, fl., G. Hatschbach 16315 (MBM). Morretes, 12.IV.1977, fl., G. Hatschbach 39871 (MBM).

Rhipsalis pachyptera difere de Rhipsalis elliptica pelo formato do ápice dos segmentos caulinares, arredondados, enquanto em $R$. elliptica são agudos a cuneados. As aréolas estéreis e férteis em $R$. pachyptera são, em sua maioria, muito maiores que as aréolas de $R$. elliptica. É encontrada no Paraná em Floresta Ombrófila Densa e Mista. 
11.8 Rhipsalis paradoxa Salm-Dyck, Cact. Hort. Dyck. 39. 1844.

Fig. $3 \mathrm{j}$

Epífitas até $5 \mathrm{~m}$ compr., pendentes. Caules esverdeados, ramificações apicais ou subapicais, 2-3-furcadas, segmentos monomórficos, alados, 3 alas, alas bifurcadas na aréola, lineares, base e ápice truncados, margens lisas, 89-320 × 2,6-8 $\times 0,7-2 \mathrm{~mm}$, nervura central 2,9-5,6 mm larg., crescimento determinado. Aréolas estéreis 1,1-1,9 $\mathrm{mm}$ larg., com escamas filiformes, aréolas férteis 2,8-4,8 mm larg., lanosas com escamas, podários desenvolvidos. Flores 1 por aréola, $12-15 \times 8,8-13$ $\mathrm{mm}$, laterais, rotáceas; pericarpelos róseos, 2,4-4 $\times 3,9-5,8 \mathrm{~mm}$, imersos no caule, campanulados, glabros; segmentos externos do perianto 1-3, alvos, 2,4-6,4 × 1,6-2,2 $\mathrm{mm}$, eretos, triangulares a lineares; segmentos internos do perianto 7-10, alvos, $5,7-12 \times 1,4-4,5 \mathrm{~mm}$, reflexos, estreitoelípticos a oblanceolados; estames 76-110, alvos, 3,5-9 mm compr.; estiletes 7,2-9,5 mm compr., 6 lobos, 1,8-3,2 mm compr.. Frutos róseos a alvos, 7,4-8,8 × 6,3-6,9 mm, globosos. Sementes 28-31, castanhas ou negras, $0,9-1,3 \times 0,5-0,8$ $\mathrm{mm}$, elípticas.

Material selecionado: Adrianópolis, 26.X.2004, fl., J.M. Silva 4161 (MBM).

Rhipsalis paradoxa é reconhecida pelo seu caule aparentemente torcido devido à posição alternas das alas. Difere de Rhipsalis trigona pelas alas paralelas à linha do caule, se dividindo dicotomicamente na aréola, enquanto em $R$. trigona as alas são paralelas à linha do caule, contínuas, antes e após as aréolas. É uma espécie rara no estado e ocorre em Floresta Ombrófila Densae Mista.

11.9 Rhipsalis pilocarpa Loefgr., Monatsschr. Kakteenk. 13: 5 2. 1903. Fig. 3k-1

Epífitas até $5 \mathrm{~m}$ compr., pendentes. Caules esverdeados, ramificações apicais, 2-3-4-(5)(6)-furcados, segmentos caulinares monomórficos, cilíndricos, $21-320 \times 2-3,7 \mathrm{~mm}$, crescimento determinado. Aréolas estéreis 0,4-1,4 mm larg., aréolas férteis 1,1-1,4 mm larg., aréolas estéreis e férteis velutinas, podários não desenvolvidos. Flores 1-2-(3) flores por aréola, $12-17 \times 7-11$ $\mathrm{mm}$, apicais, rotáceas; pericarpelos esverdeados, $3,3-5,1 \times 4,6-6 \mathrm{~mm}$, emersos do caule, piriformes, cobertos por aréolas estéreis velutinas; segmentos externos do perianto 3 , alvos, $1,7-3,7 \times 1,3-2,8$ $\mathrm{mm}$, reflexos, triangulares; segmentos internos do perianto17-21, alvos, 5,5-12 × 0,9-3,4 mm, reflexos, lineares a lanceolados; estames $50-110$, alvo com base rósea, 1,6-9,9 $\mathrm{mm}$; estiletes 8,7-9,1 mm compr., 4-7 lobos, 8,7-9,1 mm compr. Frutos róseos ou vináceos, $0,8-11,1 \times 9-10,5 \mathrm{~mm}$, globosos. Sementes 19-23, castanhas, 1,5 × 0,7 $\mathrm{mm}$, elípticas.

Material selecionado: Campina Grande do Sul, Rio Capivari, 14.VIII.1985, fl., J. Cordeiro 100 (MBM).

Rhipsalis pilocarpa é uma planta cilíndrica e pendente reconhecida pelos tricomas longos das aréolas que recobrem boa parte da superfície do caule e do pericarpelo. Foi encontrada no estado somente nas margens do Rio Capivari, na região de Floresta Ombrófila Densa e Mista, e o estado representa o limite sul de ocorrência da espécie no Brasil.

11.10 Rhipsalis teres Steud., Nomencl. Bot. [Steudel], ed. 2. 2: 449. 1841 Fig. 3m

Epífitas até $3 \mathrm{~m}$ compr., pendentes. Caules esverdeados, ramificações apicais ou subapicais, 2-3-4-(5)-(6)-(10)-furcados, segmentos com tamanho dimórfico e formato monomórfico, cilíndricos; segmentos primários $38-120 \mathrm{~cm}$ $\times 1,8-4,7 \mathrm{~mm}$, crescimento indeterminado; segmentos secundários $19-190 \times 0,5-2,5 \mathrm{~mm}$, crescimento determinado. Aréolas estéreis 0,40,9 mm larg., aréolas férteis 0,6-1,8 mm larg., aréolas estéreis e férteis com escamas filiformes, podários não desenvolvidos. Flores 1-(2) por aréola, 5,8-6,3 × 2,5-7,6 mm, apicais, subapicais ou laterais, rotáceas; pericarpelos esverdeados, 1,9-2,2 × 1,4-1,9 mm, emersos do caule, globosos, glabros; segmentos externos do perianto 2 , alvos a esverdeados, 0,4-2,4 × 0,8-2,1 mm, reflexos, triangulares; segmentos internos do perianto $4-5$, alvos, 2,3-4,1 × 0,8-3,2 mm, reflexos, elípticos a estreito-elípticos; estames 25-37, alvos, 1,1-4,4 $\mathrm{mm}$ compr.; estiletes $2,3-3,2 \mathrm{~mm}$ compr., 3 lobos, $0,5-0,9 \mathrm{~mm}$ compr. Frutos alvos ou róseos, $3,7-5,9 \times 2,9-4,9 \mathrm{~mm}$, globosos. Sementes 2-21, castanhas, $0,8-1,3 \times 0,3-0,7 \mathrm{~mm}$, elípticas.

Material selecionado: Antonina, 22.II.2011, fl., A. Soller 115 (UPCB). Campo Largo, 23.VI.1996, fr., A.C. Svolenski 251 (MBM). Cerro Azul, Rio do Turvo 19.VII.1984, fr., G. Hatschbach 48116 (MBM). Dr. Ulysses, Rio do Turvo 19.IV.2006, fl., E. Barbosa 1257 (MBM). Guaratuba, 12.III.1963, fl., G. Hatshbach 9781 (MBM). Jaguatirica, Rio Capivari, 26.V.1963, fr., G. Hatschbach 10082 (MBM). Morretes, Rio Bromado, 12.II.1985, fr., G. Hatschbach 48902 (MBM). Paranaguá, Ilha do Mel, 31.III.1988, fl., R.M. Britez 1505 (MBM). Rio Branco do Sul, 8.V.1968, fr., G. Hatschbach 19213 (MBM).

Rhipsalis teres é reconhecida pela ramificação apical ou subapical, segmentos caulinares 
cilíndricos com comprimento dimórficos, os primários longos, $38-120 \mathrm{~cm}$, e os secundários mais curtos,19-190 mm, e flores com menos de 1 $\mathrm{cm}$ de comprimento. Ocorre em todo o território do estado com frequencia maior na Floresta Ombrófila Densa e Mista.

\subsection{Rhipsalis trigona Pfeiff., Enum. Diagn. Cact.} 133. 1837.

Fig. 3n

Epífitas até $3 \mathrm{~m}$ compr., pendentes. Caules esverdeados, ramificações apicais ou subapicais, 2-3-furcados, segmentos monomórficos, alados, 3-(4) alas, alas contínuas, lineares, base e ápice truncados, margens lisas, 79-200 × 3,4-10 $\times$ 0,4-1,8 mm, nervura central 2,1-6,6 mm larg., crescimento determinado. Aréolas estéreis $0,9-1,4$ $\mathrm{mm}$ larg., glabras, aréolas férteis 2,4-4,8 mm larg., lanosas, podários não desenvolvidos. Flores 1 por aréola, 7,1-11 × 5,8-7,6 mm, laterais, rotáceas; pericarpelos róseos, 2,3-3,4×1,8-5,1 mm, imersos no caule, piriformes, glabros; segmentos externos do perianto 4, amarelados, 2,1-5 × 2,3-3,1 mm, reflexos, ovais a elípticos; segmentos internos do perianto $8-9$, amarelados, $3,6-7,2 \times 2-3,5 \mathrm{~mm}$, reflexos, lanceolados a oblanceolados; estames 52-70, alvos, 1,3-5 mm compr.; estiletes 2-4,2 mm compr., 4-7 lobos, 0,8-2,4 mm compr. Frutos purpúreos, 6,3-6,4 × 4,2-4,7 $\mathrm{mm}$, globosos. Sementes 23-67, castanhas, 1,3-1,9 × 0,7-0,9 $\mathrm{mm}$, elípticas.

Material selecionado:Turvo, 6.VII.1989, fl., G. Hatschbach 53166 (MBM).

Rhipalis trigona é reconhecida pelo seu caule com seção trígona. Difere de Rhipsalis paradoxa pelas alas paralelas à linha do caule, contínuas, antes e após as aréolas, enquanto que em $R$. paradoxa as alas são paralelas à linha do caule, se dividindo dicotomicamente na aréola. É uma espécie rara no estado, encontrada nas Floresta Ombrófila Densa e Mista.

12. Schlumbergera Lem., Rev. Hort. [Paris]. Ser. 4, 7:253. 1858.

Plantas arbustivas, epífitas, até $40 \mathrm{~cm}$ compr., pendentes, ramificação apical ou subapical. Caule segmentado, monomórfico, 2-(3)-(4)-(5)-alados, $0,15-6 \times 0,2-4,5 \mathrm{~cm}$ compr., com crescimento determinado. Folhas ausentes. Aréolas dispostas nas margens do caule, glabras ou pubescentes; espinhos 0-80, aciculares. Flores 1,5 a $9 \mathrm{~cm}$ compr., apicais ou subapicais, campanuladas, alvas, avermelhadas, purpúreas ou róseas; pericarpelo glabro; antese diurna. Frutos globosos ou angulados, cerca de $1 \mathrm{~cm}$ compr., alvos, amarelados ou esverdeados. Sementes ovais a reniformes, castanhas a negras, lisas.

Gênero com nove espécies distribuídas no Brasil, duas das quais ocorremno Paraná. Os indivíduos adultos desse gênero se assemelham com os indivíduos jovens das espécies aladas de Rhipsalis. As plantas estéreis nesse estágio de desenvolvimento podem ser reconhecidas pela base recoberta por periderme nos indivíduos de Schlumbergera, pois as espécies aladas de Rhipsalis, quando jovens, não possuem tal característica, e, quando adultos, possuem as alas muito maiores.

Optou-se em seguir Calvente et al. (2011) que,baseada em dados moleculares, transferiu ambas as espécies do gênero Hatiora para Schlumbergera e deu o tratamento taxonômico adequado ao trocá-las de gênero, ao contrário de Korotkova et al. (2011) que apenas sugeriram que $S$. gaertneri e $S$. rosea sejam transferidas para o gênero Rhipsalidopsis. O estado representa o limite norte de ocorrência de ambas as espécies no Brasil.

\section{Chave para identificação das espécies de Schlumbergera}

1. Segmentos internos do perianto vermelhos a alaranjados,lanceolados a estreito-elípticos; margens dos segmentos caulinares crenadas 1. Schlumbergera gaertneri

1'. Segmentos internos do perianto róseos a alvos,elípticos a oblanceolados; margens dos segmentos caulinares lisas 2. Schlumbergera rosea

12.1 Schlumbergera gaertneri (Regel) Britton \& Rose, Contr. U.S. Natl. Herb. 16: 260. 1913.

Fig. $2 n$

Epífitas até $30 \mathrm{~cm}$ compr., pendentes. Caules esverdeados, ramificações apicais, 2(3)-furcados, segmentos monomórficos, alados,
2 alas, alas contínuas, elípticos a obovados, base aguda a cuneada, ápice arredondado, margens crenadas, crenas arredondadas, 9,5-75,2 $\times$ $9,6-31 \times 0,6-4 \mathrm{~mm}$, nervura central 1,9-3,7 mm larg., crescimento determinado. Aréolas estéreis 0,4-1,2 mm larg., aréolas férteis 1,3-3,2 mm larg., 
aréolas estéreis e férteis pubescentes, podários não desenvolvidos. Flores 1 por aréola, 25-62 $\times$ 6,3-38 mm, apicais, campanuladas; pericarpelos esverdeados a castanhos, 5,9-11 × 4,6-7,4 mm, emersos do caule, campanulados, 4-costados, glabros; segmentos externos do perianto 3-4, vermelhos a alaranjados, $0,7-8,3 \times 3,2-6,1 \mathrm{~mm}$, eretos, triangulares; segmentos internos do perianto $8-18$, vermelhos a alaranjados, $6,1-57 \times 1,6-5 \mathrm{~mm}$, eretos, lanceolados a estreito-elípticos; estames 78-143, róseos com anteras amarelas, 1,7-19,4 mm; estiletes 6,4-19 mm compr., 5-7 lobos, 2,6-5,7 mm compr. Frutos não vistos.

Material selecionado: Morretes, 1.IX.2009, fl., R.R. Voltz 59 (UPCB). Quatro Barras, 7.XI.1992, fl., A.C.. Cervi 3891 (UPCB). Tijucas do Sul, 6.XI.1998, fl., E. Barbosa 199 (MBM). São José dos Pinhais, Guaricana, 1.XI.1977, fl., G. Hatschbach 40258 (MBM).

Schlumbergera gaertneri é uma espécie comumente utilizada como planta ornamental. É caracterizada pela cor vermelha do perianto e possui os ápices dos segmentos externos do perianto agudos. É encontrada no Paraná nas regiões preservadas da Floresta Ombrófila Densa em Matas Nebulares.

12.2. Schlumbergera rosea (Lagerh.) Calvente \& Zappi, Mol. Phyl. Evol. 58. $2011 . \quad$ Fig. 2o

Epífitas até $40 \mathrm{~cm}$ compr., pendentes. Caules esverdeados, ramificações apicais, 2-3-furcados, segmentos monomórficos, alados, 2 alas, alas contínuas, obovados a oblongos, base aguda a cuneada, ápice arredondado a truncado, margens lisas, 8,8-47 × 3,4-14 × 0,2-1,4 mm, nervura central 1,2-3,8 mm larg. Aréolas estéreis $0,4-1,3$ $\mathrm{mm}$ larg., aréolas férteis 1,3-3,6 mm larg., aréolas estéreis e férteis pubescentes, podários não desenvolvidos. Flores 1 por aréola, 19-40 × 9,6-20 $\mathrm{mm}$, apicais, campanuladas; pericarpelos verdes a castanhos, 5,9-11 × 4,6-7,4 mm, emersos do caule, campanulados, 4-costados, glabros; segmentos externos do perianto 5-8, alvos a róseos, $0,8-8,2$ $\mathrm{mm} \times 1,4-4,9 \mathrm{~mm}$, eretos, triangulares a elípticos; segmentos internos do perianto 13-17, róseos a alvos, 7,8-18 ×3,3-5,7 mm, eretos, elípticos a oblanceolados; estames 54-80, róseos com anteras amarelas, 2,4-15 mm compr.; estiletes 8,3-10 mm compr., 4-5 lobos, 2,7-3,5 mm compr. Frutos não vistos.

Material selecionado: Campina Grande do Sul, Pico do Paraná, 24.X.2005, f1., O.S. Ribas 7019 (MBM). Quatro Barras, Serra Capivari Grande, 27.X.1997, fl., A.C.Cervi 7053 (UPCB). Morretes, Serra do Marumbi 13.XI.1970, fl., G. Hatschbach. 25389 (MBM). Piraquara, Torre da Vigia, 29.IX.2004, fl., E.F. Costa 2 (MBM).
Schlumbergera rosea é uma espécie comumente utilizada como planta ornamental. É caracterizada pela cor rosa do perianto, e pelos segmentos externos do perianto com ápice arredondado. É encontrada no Paraná nas regiões preservadas da Floresta Ombrófila Densa em matas nebulares.

\section{Agradecimentos}

Agradecemos ao CNPq/CAPES através do PROTAX (Programa de Capacitação em Taxonomia: Flora de Plantas Vasculares do Paraná), a bolsa de mestrado concedida a André Soller; à Fundação Araucária e ao CNPq (Projeto $\mathrm{n}^{\mathrm{o}}$ 474064.2010-7; Edital Universal MCT/CNPq/ MEC/CAPES/PROTAX n ${ }^{\circ} 52.2010$ ), a bolsa de produtividade para Renato Goldenberg, ao Instituto Ambiental do Paraná, a licença de coleta, aos curadores de todos os herbários visitados e a todos os funcionários dos parques visitados, o apoio durante as visitas.

\section{Referências}

Anderson, E.F. 2001. The cactus family. Timber Press, Portland. 776p.

Angely, J. 1965. Flora analítica do Paraná. Phyton, São Paulo. 728p.

Barthlott, W. \& Hunt. D.R. 1993. Cactaceae. In: Kubitzki, K.; Rohwer, J.G. \& Bittrich, V. (eds.). The families and genera of vascular plants. Dycotyledons. Vol. 2. Springer Verlag, Heidelberg. Pp.161-196.

Barthlott, W. \& Taylor, N.P. 1995.Notes towards a monograph of Rhipsalideae (Cactaceae). Bradleya 13: 43-79.

Britton, N.L. \& Rose, J.N. 1923. The Cactaceae: descriptions and illustrations of plants of the cactus family. Vol. 4. The Carnegie Institution of Washington, Washington, DC. 321p.

Calvente, A.; Zappi, D.C.; Forest, F. \& Lohmann, L.G. 2011.Molecular phylogeny of tribe Rhipsalideae (Cactaceae) and taxonomic implications for Schlumbergera and Hatiora. Molecular Phylogenetics and Evolution 58: 456-468.

Edwards, E.J.; Nyffeler, R. \& Donoghue, M.J. 2005. Basal cactus phylogeny: implications of Pereskia (Cactaceae) paraphyly for the transition to the cactus life form. American Journal of Botany 92:1177-1188.

Gibson, A.C. \& Nobel, P.S. 1986. The cactus primer. Harvard University Press, Cambridge. 296p.

Gonçalves, E.G. \& Lorenzi, H. 2007. Morfologia vegetal. Instituto Plantarum, São Paulo. 445p.

Hunt, D.; Taylor, N. P. \& Charles, G. 2006. The new cactus lexicon.Vol. 2. DH Books, Milborn Port. 526p. 
Korotkova, N.; Borsch, T.; Quandt, D.; Taylor, N.P.; Müller, K.F. \& Barthlott, W. 2011. What does it take to resolve relationships and to identify species with molecular markers? An example from the epiphytic Rhipsalideae (cactaceae). American Journal of Botany 98: 1549-1572.

Lawrence, G.H.M. 1955. An introduction to plant taxonomy. Macmillan, New York. 179p.

Loefgren, A. 1915.O gênero Rhipsalis. Arquivos do Jardim Botânico do Rio de Janeiro 1: 59-104.

Loefgren, A. 1917. Novas contribuições para o gênero Rhipsalis. Arquivos do Jardim Botânico do Rio de Janeiro 2: 34-45.

Nyffeler, R. 2002. Phylogenetic relationships in the cactus family (Cactaceae) based on evidence from trnK.matK and trnL-trnF sequences. American Journal of Botany 89: 312-326.

Oliveira Jr., H.F. 1997. A família Cactaceae na integração Parque Estadual de Vila Velha - Rio São Jorge, Ponta Grossa, Paraná - Brasil. Dissertação de Mestrado. Universidade Federal do Paraná, Curitiba. 109p.

Scheinvar, L. 1985. Cactáceas. Flora Ilustrada Catarinense. Fascículo CACT. Herbário Barbosa Rodrigues, Itajaí. 383p.

Schumann, K. 1890. Cactaceae. In: Martius, C.F.P.; Eichler, A.W. \& Urban, I. (eds.). Flora brasiliensis. Munchen, Wien, Leipzig. Vol. 4. Pp. 185-322.

Thiers, B. [continuously updated]. Index Herbariorum: a global directory of public herbaria and associated staff. New York Botanical Garden's Virtual Herbarium. Disponível em $<$ http://sweetgum.nybg. org/ih.>. Acesso em 2 Set 2012.

SOS Mata atlântica, 2012. Disponível em <http:www. mapas.sosma.org.br>. Acesso em 13 Mar 2012.
Taylor, N.P. 1997. Cactaceae. In: Oldfield, S. (ed.). Cactus and succulent plants - status survey and conservation action plan. IUCN, SSC Cactus and Succulent Specialist Group, Gland, Cambridge. Pp. 17-20.

Taylor, N.P. \& Zappi, D.C. 2004. Cacti of eastern Brazil. The Royal Botanic Gardens, Kew. 511p.

Veloso, H.P.; Rangel Filho, A.L.R. \& Lima, J.C.A. 1991. Classificação da vegetação brasileira, adaptada a um sistema universal. IBGE, Rio de Janeiro. 123p.

Wallace R.S. 1995. Molecular systematic study of the Cactaceae: using chloroplast DNA variation to elucidate cactus phylogeny. Bradleya 13: 1-12.

Wallace, R.S. \& Cota, J.H., 1996. An intron loss in the chloroplast gene rpoC1 supports a monophyletic origin for the subfamily Cactoideae of the Cactaceae. Current Genetics. 29: 275-281.

Wallace, R.S. \& Gibson, A.C. 2002. Evolution and systematics. In: Nobel, P.S. Cacti: biology and uses. University of California Press, Berkeley. Pp. 1-21.

Zappi, D.; Aona, L.Y.S. \& Taylor, N., 2007.Cactaceae. In: Wanderley, M.G.L.; Shepherd, G.J.; Melhem, T.S. \& Giulietti, A.M. Flora fanerogâmica do estado de São Paulo. Vol. 5. Instituto de Botânica, São Paulo. Pp. 163-193.

Zappi, D.; Taylor, N.\& Machado, M. 2010. Cactaceae. In: Lista de espécies da flora do Brasil. Jardim Botânico do Rio de Janeiro. Disponível em $<$ http:// floradobrasil.jbrj.gov.br.2010.FB000070>. Acesso em 20 Set 2011.

Zuloaga, F.O.; Morrone, O. \&Belgrano, M.J. 2008. Catálogo de las plantas vasculares Del Cono Sur (Argentina, sur de Brasil, Chile, Paraguay y Uruguay). Monogr. Syst. Bot. Missouri Bot. Gard. Disponível em <http:// www2.darwin.edu.ar $>$ Proyectos.FloraArgentina. FA.asp>. Acesso em 22 Set 2011. 